\title{
Decoding Inside Information
}

\section{Citation}

COHEN, LAUREN, CHRISTOPHER MALLOY, and LUKASZ POMORSKI. 2012. “Decoding Inside Information." The Journal of Finance 67 (3) (May 21): 1009-1043. Portico. doi:10.1111/ j.1540-6261.2012.01740.x. .

\section{Permanent link}

http://nrs.harvard.edu/urn-3:HUL.InstRepos:33785679

\section{Terms of Use}

This article was downloaded from Harvard University's DASH repository, and is made available under the terms and conditions applicable to Open Access Policy Articles, as set forth at http:// nrs.harvard.edu/urn-3:HUL.InstRepos:dash.current.terms-of-use\#OAP

\section{Share Your Story}

The Harvard community has made this article openly available.

Please share how this access benefits you. Submit a story.

\section{Accessibility}




\title{
Decoding Inside Information
}

\author{
LAUREN COHEN, CHRISTOPHER MALLOY, and LUKASZ POMORSKI*
}

\begin{abstract}
Exploiting the fact that insiders trade for a variety of reasons, we show that there is predictable, identifiable "routine" insider trading that is not informative for the future of firms. A portfolio strategy that focuses solely on the remaining "opportunistic" traders yields value-weighted abnormal returns of 82 basis points per month, while abnormal returns associated with routine traders are essentially zero. The most informed opportunistic traders are local, non-executive insiders from geographically concentrated, poorly governed firms. Opportunistic traders are significantly more likely to have SEC enforcement action taken against them, and reduce trading following waves of SEC insider trading enforcement.
\end{abstract}

JEL Classification: Insider trading, information flow, asset prices

Key words: G12, G14, G18

\footnotetext{
* Cohen and Malloy are at the Harvard Business School and NBER; Pomorski is at the University of Toronto. We would like to thank Dan Bergstresser, Sabrina Buti, John Campbell, Jeff Coles, Josh Coval, Chuck Dale, Craig Doidge, Esther Eiling, Ben Esty, Fritz Foley, Cam Harvey, Harold Hau, Inigo FraserJenkins, Julian Franks, Robin Greenwood, Raymond Kan, Inmoo Lee, Jan Mahrt-Smith, Jennifer Marietta-Westberg, Jacob Oded, Jeff Pontiff, Bryan Routledge, Nejat Seyhun, Tao Shu, Rick Sias, Sunil Wahal, Jason Wei, the Associate Editor, an anonymous referee, and seminar participants at the United States Securities and Exchange Commission (SEC), AQR Capital, Arrowstreet Capital, Binghamton, Dartmouth University, Harvard Business School, University of Missouri, the Canada Pension Plan Investment Board, the Chicago Quantitative Alliance Annual Fall Conference, the China International Conference, the Center for Research in Securities Prices (CRSP) Forum, the European Finance Association Meeting in Frankfurt, the Inquire UK Conference in Cambridge, the Rothschild Caesarea Center 7th Annual Conference, Universidad Autonoma de Barcelona, and the Western Finance Association Meeting in Victoria for helpful comments and suggestions. We thank David Kim for outstanding research assistance, and we are grateful to Diego Garcia and Oyvind Norli for providing data on geographic locations of firm operations. We gratefully acknowledge funding from the National Science Foundation. We are also grateful for funding from INQUIRE UK. This article represents the views of the authors and not of INQUIRE.
} 
Investors and regulators share a common challenge: how to sift through the multitude of information events that bombard securities markets each day, and determine which events contain viable information, and which do not. Investors in these markets must ascertain which of these events, and what parts of their contents, have insight into firm value. Regulators, on the other hand, must work to ensure that information flow in the capital markets is "timely, comprehensive and accurate." ${ }^{1}$

A class of information events that is especially difficult to decipher is the trading activity of corporate insiders. Insiders are a unique class of traders as they, by definition, have favored access to private information about the given firm. Because of this preferential access, insiders are subject to increased scrutiny, regulation, and restrictions regarding their trading activities.

Another unique aspect of insiders is that they often receive a large proportion of their stakes in firms through non-market transactions (e.g. stock grants). Through initial ownership, stock grants, and other market transactions, insiders' firm stockholdings are often a non-trivial percentage of their wealth. Thus personal liquidity and diversification motives, in addition to signaling and regulatory issues, will affect the timing and nature of insider trades, making it more difficult for investors to interpret any given insider trade as informative or not.

The detection of illegal insider trading, meanwhile, presents an even higher hurdle: the U.S. Securities and Exchange Commission (SEC) must demonstrate that a person "trades a security while in possession of material nonpublic information in 
violation of a duty to withhold the information or refrain from trading." ${ }^{2}$ The rash of high-profile insider trading cases in recent years, notably the government's investigation into the Galleon Group in late 2009--the largest hedge fund insider trading case in U.S. history--indicates that the SEC continues to expend substantial resources trying to address this difficult problem.

In this paper we provide a new framework for thinking about detection and information flow in the capital markets. Using a simple, novel approach, we decode whether there is likely to be information in a given insider's trades. In doing so, we show that there is predictable, identifiable "routine" insider trading that is not informative for the future of firms. Classifying trading in this way allows us to strip away these uninformative signals, leaving a set of information-rich trades by "opportunistic" insiders that contain all of the predictive power in the insider universe.

Our analysis rests on the simple idea that insiders, while possessing private information, trade for many reasons. For example, routine sells by insiders are commonplace in the market, and can be driven by diversification or liquidity reasons, with the insider wanting to signal that he is not trading on information about the firm (e.g., Bill Gates, who trades in a pre-announced, routine fashion). Routine buys, on the other hand, may occur after an insider receives a bonus; since bonuses are often paid out in the same month each year, and since insiders often receive discount plans on their company stock (and hence are more likely to buy the stock), insider buying in the same calendar month is common and often uninformative. Thus, if one can classify ex-ante 
those traders who make routine (and so less informative) trades, one can better identify the true information that insiders contain and thus develop a richer understanding of firm-level asset prices.

To better understand our approach, consider the following example from our sample. ${ }^{3} \quad$ ABC Inc. is a large, publicly traded firm, which in 1997 operated in all 50 states, and in over 40 countries worldwide. The firm had a number of insiders. In particular, two of these insiders, Mr. Smith and Mr. Johnson (both board members), were actively trading over their times at ABC Inc., but in starkly different ways. Mr. Smith had been trading in every April in the years prior to 1997, and in 1997 he again put on his usual April trade. Mr. Johnson, in contrast, had been active over the same period, but had no patterns in his trading, trading some years in March, some years in August, some years in September, etc. Further, they had quite different returns to their insider trading.

Looking deeper into their trades, following Mr. Smith's 1997 sale of ABC stock in April, the value of $\mathrm{ABC}$ Inc. actually rose in the following month by $3.2 \%$ (so a $-3.2 \%$ return). In contrast, following Mr. Johnson's sale of ABC stock in December the stock plummeted after the subsequent revelation of two key pieces of news. First, in the following month, when earnings were announced, ABC announced that customer defections remained a problem, and projected that the defections would continue in 1998. ABC's price dropped over $5 \%$ on this news (even though ABC otherwise hit the consensus analysts' earnings target), then dropped another $2 \%$ the following day, for a 
2-day drop of over $7 \%$. In addition to this, 8 days following the earnings announcement, it was announced that $\mathrm{ABC}$ Inc. was being formally investigated by a large state government for mishandling of numerous dealings it had with the state. In the 2 days following the release of this news, ABC Inc. dropped another 3.5\%. The total return of ABC Inc. following the month of Mr. Johnson's stock sale was $-12.6 \%$. We illustrate the returns and events following Mr. Johnson's trades in Appendix Figure $\mathrm{A} 1 .^{4}$

Had one taken the simple strategy of replicating Mr. Johnson's trades (who we term as an "opportunistic insider" throughout the paper), one would have made over $12 \%$ in the following month. In contrast, had one replicated the trades of the other insider Mr. Smith (who we term as a "routine insider", given his usual, routine trading pattern), one would have made $-3.2 \%$ (since the price of $\mathrm{ABC}$ actually rose following his trades).

In this paper we demonstrate that the above example of $\mathrm{ABC}$ Inc. represents a much more systematic pattern across the entire universe of corporate insiders and publicly traded firms. We are able to systematically and predictably identify insiders as either opportunistic or routine traders throughout our sample period (1986-2007). Further, our classification scheme essentially divides the insider trading universe in half. We show that the abnormal returns associated with routine traders are essentially zero, indicating that our approach is able to weed out more than half the universe of insider trades, and specifically the half that has no predictive power for future returns or firm 
news. Meanwhile, the half that remains contains all of the predictive power in the insider trading universe.

One other interesting aspect of Mr. Smith and Mr. Johnson are their backgrounds. Both of these insiders were directors, sitting on the board of $\mathrm{ABC}$ Inc. in 1997. However, Mr. Johnson resided in the same city as ABC Inc., and so was a local insider, while Mr. Smith lived in a completely different state. We show that this characteristic of being geographically 'local' is common to the most informed opportunistic traders.

Our empirical strategy for identifying routine traders is simple. For each insider, we analyze her past trading history, and look for consistent patterns in the timing of trades. Specifically, we define a routine trader as an insider who placed a trade in the same calendar month for at least a certain number of years in the past. We then define opportunistic traders as everyone else, i.e. those insiders who have traded in the same years as the routine insiders, but for whom we cannot detect an obvious discernible pattern in the past timing of their trades. We thus designate all insiders as either routine traders or opportunistic traders at the beginning of each calendar year, based on their past history of trades, and then look to see how they trade from that point onwards. While this designation is made at the individual trader-level (i.e., classifying the insider as opportunistic or routine), we also use a trade-level classification (so that the same insider can have both routine and opportunistic trades), and obtain similar results and insights. 
We show that focusing only on the trades of opportunistic traders allows us to weed out uninformative signals and identify a set of information-rich trades that are powerful predictors of future firm returns, news, and events. In addition, we provide insight into exactly what kind of information these opportunistic traders are trading on, who these informed opportunistic traders are, and which other market participants are following their trades. Finally, we highlight the links between our opportunistic classification and SEC enforcement activities.

To give an idea of the stark differential in information revealed by these opportunistic vs. routine insiders, a long-short portfolio that exploits solely the trades of opportunistic traders (opportunistic buys minus opportunistic sells) earns valueweighted abnormal returns of 82 basis points per month (9.8 percent annualized, $t=2.15)$, and equal-weighted abnormal returns of 180 basis points per month (21.6 percent annualized, $t=6.07)$. Meanwhile, a portfolio that mimics the behavior of routine traders (routine buys minus routine sells) earns value-weighted returns of -20 basis points per month $(t=-0.57)$, and equal-weighted returns of only 43 basis points per month $(t=1.73)$. We also demonstrate that an alternate approach for identifying routine trading - focusing on trade-level patterns within a given insider, and thus allowing a given insider to be both routine and opportunistic at different times - yields similar inferences regarding the predictive power of routine versus opportunistic trades. Finally, although our baseline classification procedure requires three years of past trading history in order to categorize a given insider, and hence restricts our main 
sample to a subset of the entire insider universe, we find that the "non-classified" trades that we exclude can be grouped into either the opportunistic or routine category without affecting our results; if anything, these non-classified trades appear to more closely resemble opportunistic trades rather than routine trades.

We show that over half of the improvement in predictive power gained by focusing on opportunistic trades comes from the superior performance of opportunistic sells relative to routine sells; this is in contrast to much of the literature (e.g., Jeng et al. (2003)), which generally finds weak evidence on the profitability of insider sales. Further, we find that the returns to these opportunistic trades continue to rise for roughly six months following the opportunistic trading month, and then level off, exhibiting no future reversal. Thus, it appears that the information being conveyed through the trades of opportunistic insiders has lasting implications for firm values.

Importantly, we then examine the drivers of the large information differences revealed by opportunistic vs. routine traders. Specifically, we begin by exploring exactly what firm-level information these opportunistic insiders appear to have the ability to predict. We find that the trades of opportunistic insiders show significant predictive power for future news announcements about the firm, while trades by routine insiders do not. Looking deeper into exactly what kind of news these opportunistic traders predict, we find that opportunistic insiders have statistically significant predictive power for announcement returns around: future analyst recommendations, future analyst earnings forecasts, future management forecasts, and future earnings announcements. 
Again, routine traders show no predictive ability for these events.

We next examine the characteristics of these opportunistic traders. We first find that the trades of local non-senior (i.e., not the $\mathrm{CEO}, \mathrm{CFO}$, or Chairman of the Board) opportunistic traders have the most predictability for future firm events. We find that these informed local non-senior opportunistic traders share a number of characteristics. First, they tend to have a longer relationship with the firm than the average insider, and so perhaps more time to build a level of (or access to) information about the firm. Second, they are more likely to be from geographically concentrated firms (i.e., firms that have all of their operations in a single state). These may be the exact firms where we might expect a local advantage to be most valuable. Third, they are more likely to be from poorly governed firms, which is consistent with the idea that informative insider trading is more likely to take place where monitoring and institutional controls are weaker. Lastly, they come from firms with more product offerings, suggesting that firms that produce lots of products, many of which may be hard to evaluate from the outside, tend to be places where the marginal benefit of inside information is largest.

We then show links between our opportunistic classification and enforcement actions taken by the SEC. The motivation behind these tests is that one possible way to view our classification scheme is as a systematic way that enforcement officials could examine insider trading, rather than on a case-by-case basis. Indeed, we show two interesting relationships between our classification and SEC enforcement activities. First, our classification scheme correctly identifies many of the high-profile insiders who 
were later charged for illegal insider trading as opportunistic traders: e.g., Kenneth Lay (Founder and Chairman of Enron), Jeff Skilling (CEO of Enron), Joseph Nacchio (CEO of Qwest Communications), Victor Menezes (Senior Vice Chairman of Citigroup), and David Willey (CFO of Capital One). In a more systematic way, we find that opportunistic trading significantly increases the likelihood of future SEC enforcement action, while routine trading does not. Second, consistent with the idea that opportunistic traders dampen their trading activity when the potential costs of illegal insider trading increase, we find that the fraction of traders who are opportunistic in a given month is negatively related to the number of recent news releases by the SEC regarding illegal insider trading cases. We also show suggestive evidence that institutional investors have some ability to decipher between the on average informed opportunistic trades and uninformed routine traders. Institutional investors appear to mimic opportunistic trades in the quarter following these trades (but not routine insider trades). They couple this with providing liquidity to the uninformed routine traders in the contemporaneous quarter (with no such contemporaneous relationship with opportunistic traders).

Lastly, we perform a variety of robustness checks. First, we show that the intensity of opportunistic trading (both trade-weighting and using number of trades) has significant predictive ability for future returns, while intensity of routine trading shows no such relation. Also we verify that our results are not concentrated in certain types of stocks, or at certain specific times. We show that our main result that 
opportunistic trades are more informative than routine trades holds for both large stocks and small stocks, both heavily-traded stocks and lightly-traded stocks, both inside and outside explicit "blackout" periods, and across both the NYSE and NASDAQ stock exchanges.

The remainder of the paper is organized as follows. Section I of the paper provides a brief background and literature review. Section II describes our data on insider transactions, as well as the other data we use in the paper. Section III provides the main results on the performance of opportunistic traders versus routine traders. Section IV explores which information events these opportunistic traders predict, as well as the link between institutional trading and opportunistic trading. Section V investigates which types of opportunistic insiders are the most informed, and the characteristics of these insiders. Section VI examines the response of opportunistic trading to SEC activity, as well as the predictors of SEC investigations. Section VII concludes.

\section{The setting}

The trades of corporate insiders are among the most widely scrutinized activities in the stock market each day. Regulators, investment managers, media members, and academics continually parse these trades for signs of illicit behavior, and for signals about a company's future prospects. Not surprisingly, the widespread interest in insider trading has spawned a large empirical literature, most of which examines the crosssectional return forecasting ability of insider trades aggregated at the firm level. For 
example, a large number of papers (see, for example Lorie and Niederhoffer (1968), Jaffe (1974), Seyhun (1986, 1998), Rozeff and Zaman (1988), Lin and Howe (1990), Bettis, Vickery, and Vickery (1997), Lakonishok and Lee (2001), and Marin and Olivier (2008)) focus on the abnormal returns to firms in relation to various metrics of firm-level insider trading frequency over well-defined periods. Seyhun (1998) summarizes this evidence and reports that several different trading rules lead to profits. ${ }^{5}$ Similarly, Jeng et al. (2003) take a performance-evaluation perspective and find that insider purchases earn abnormal returns of more than $6 \%$ per year, while insider sales do not earn significant abnormal returns.

By contrast, our focus is on the individual insiders themselves and their past trading records, and as such our approach tries to isolate predictable variation in the informativeness of insider trades by identifying which insiders are likely to be trading on information and which are not. While numerous papers study the cross-sectional variation of future stock returns as a function of past insider-trading activity, few papers share our micro-level focus on examining the characteristics and trading behavior of individual insiders in order to identify informed trading. A notable exception is Scott and $\mathrm{Xu}$ (2004), who attempt to isolate information-driven insider trading and show that shares traded as a percentage of insiders' holding contains predictive power for future returns. Jenter (2005) also tries to filter out non-informative insider trades by controlling for recent changes in the value of managers' equity stakes (in order to rule out diversification or rebalancing motives), but finds no predictive power of managers' 
insider trades for future returns.

Since a key goal of our paper is also to understand what types of events our opportunistic (i.e., informed) traders predict, our findings are also related to a series of papers, many in the accounting literature, that examine insider trading around/before various types of firm events. For example, with respect to future earnings news, Piotroski and Roulstone (2005) show that insider trades reflect both contrarian beliefs and superior information about future cash flow realizations, while Ke, Huddard and Petroni (2003) demonstrate that insiders trade before significant accounting disclosures as much as two years prior to the disclosure. ${ }^{6}$ In related work, Kahle (2000) finds that the long-run performance after seasoned equity offerings is significantly related to measures of insider trading, while Clarke, Dunbar, and Kahle (2001) provide evidence consistent with insiders exploiting windows of opportunity by trying to issue overvalued equity. Jagolinzer (2009) provides more evidence of strategic trading by insiders by focusing on a small sample of insiders who publicly disclose 10b5-1 plans (these plans came into existence in late 2000 and permit an insider to pre-specify her buys and sells on a given firm); he finds that insiders initiate sales plans before bad news and terminate sales plans before good performance. ${ }^{7}$ Note that our evidence in this paper pre-dates the existence of these plans: e.g., we find very similar differential performance of opportunistic versus routine trades before 2000, suggesting that our results are not driven by trades in these plans. 
Lastly, since we analyze the link between opportunistic insider trading and institutional trading in this paper, our findings complement prior studies that have explored the connection between insider trades and institutional trades. For example, Sias and Whidbee (2010) find a strong inverse relation between insider trading and institutional demand the same quarter and over the previous year, consistent with the idea that institutional investors are more likely to provide the liquidity necessary for insiders to trade, and that institutions and insiders are attracted to opposite security characteristics. We present suggestive evidence that institutions follow the trades of past opportunistic insider trades (particularly opportunistic buys), and also provide liquidity to contemporaneous routine buys; in doing so we provide added insight into the relation documented in Sias and Whidbee (2010).

\section{Data}

The data in this study are collected from several sources. Our primary data on insider trades are drawn from the Thomson Reuters insider filings database. Section 16a of the Securities and Exchange Act of 1934 requires that open-market trades by corporate insiders be reported to the Securities and Exchange Commission (SEC) within 10 days after the end of month in which they took place. This 10-day deadline was later changed to a 2-day deadline in 2002. The median delay between trade date and report date over our entire 22 year sample is 3 days.

Corporate insiders include officers with decision-making authority over the 
operations of the firm, all board members, and beneficial owners of more than $10 \%$ of a company's stock. These reports, filed on the SEC's Form 4, contain information about each insider transaction and about each insider's relationship to the firm. ${ }^{8}$ Our data are drawn from these Form 4 filings for the period January, 1986 to December, 2007. Our analysis focuses on open-market purchases and sales by insiders, and hence we exclude options exercises and private transactions. We merge our insider transaction data with firm-level data from CRSP/Compustat, including monthly stock returns, market capitalization figures, and book-to-market ratios.

For our tests involving insider trades before news announcements, we extract headline news data from various newswires using the Factiva web interface. First, we use the CRSP monthly stock name file to identify all company names of CRSP firms between 1989 and 2007. We then select all the Dow Jones Newswires, as well as other newswires, that are available on Factiva. For each stock on the CRSP tape we extract all the news events where the firm's name (or any of the names if multiple names exist for a given stock) is mentioned in either the headline or in the lead paragraph. We restrict the search to news items in English containing at least 5 words. We exclude republished news and recurring pricing or market data. For every news item we retain the headline, the release date, the release time, the word count and the data source. The final sample includes 2,956,862 headlines for 12,455 stocks between the years 1989 to 2000. The reason we include news data only up to 2000 is that Factiva had a structural break in their indexing system in that year, and hence from 2000 onwards indexed many 
fewer firms in the news articles in its data.

Table I presents summary statistics for our sample. This table presents an overview of the Thomson Reuters insiders database, as well as the subset of the data for which we can define the "routine" and "opportunistic" traders that feature in our analysis. As noted earlier, routine trades are made for a variety of reasons. For example, routine sells by insiders are often driven by diversification or liquidity reasons, with the insider wanting to signal that he is not trading on information about the firm (e.g., Bill Gates). Routine buys, on the other hand, may occur after an insider receives a bonus; since bonuses are generally paid out in the same month each year, and since insiders often receive discount plans on their company stock (and hence are more likely to buy the stock), insider buying in the same calendar month is common and often uninformative.

We require an insider to make at least one trade in each of the three preceding years in order to define her as either an opportunistic or a routine trader. Specifically, we then define a routine trader as an insider who placed a trade in the same calendar month for at least three consecutive years. ${ }^{9}$ We define opportunistic traders as everyone else, i.e. those insiders for whom we cannot detect an obvious discernible pattern in the past timing of their trades. We thus designate all insiders as either routine traders or opportunistic traders at the beginning of each calendar year, based on their past history of trades, and then look to see how they trade from that point onwards. All subsequent trades that are made after we classify each insider as either routine or opportunistic are 
then placed into one of two buckets: a) "routine trades" (i.e., all trades made by routine traders), and b) "opportunistic trades" (i.e., all trades made by opportunistic traders). In Exhibit A1 in the Appendix we provide a series of hypothetical traders by an insider, in order to further illustrate the timing and specifics of our approach.

Note that this simple algorithm for identifying routine buying or selling by insiders is clearly a noisy proxy for actual routine trading; our strategy will not perfectly and correctly classify each and every insider trade. But the essence of our approach is that on average, trades made for information reasons are less likely to be regular in their timing, and trades made for liquidity and diversification reasons are more likely to be regular in their timing. We have experimented with a variety of alternate measures (which yield similar results) ${ }^{10}$ but these simple measures are sufficient to illustrate our main point. Importantly, as noted above, if we alter our classification scheme in order to exploit trade-level patterns within a given insider--and thus allow a given insider to be both routine and opportunistic at different times--we again find similar results on the relative predictive power of routine versus opportunistic trades; these results are described in Section III.

As an independent verification for our classification scheme of opportunistic vs. routine traders, we examine the trading of the two different types of traders around likely stock grant dates. If we are truly capturing routine trading, it would be good to see this trading being higher around likely stock grant dates. We use fiscal year end dates of firms as this has been shown to be a quite common date for grants (Norton and 
Porter (2010)). We find many more routine trades in the quarter following a fiscal year-end compared to opportunistic trades. Specifically, we find that $58 \%$ of buys $(75 \%$ of sells) are routine in the quarter after the fiscal year end, but that only $38 \%$ of buys (52\% of sells) are routine in other quarters. This finding fits with our simple classification identifying routine trades, as they are significantly more likely to occur during times when regular, non-informative, liquidity-inducing events (such as stock grants) take place.

Table I indicates that by implementing our routine trade identification assumptions (e.g., requiring three years of past insider transactions), our final sample (Partitionable Sample) is about one-third the size of the entire sample of insider transactions. $^{11}$ Panel A shows that our sample is tilted towards bigger stocks, and slightly towards growth stocks (i.e., lower book-to-market ratios). We can also see this in Figure A2 in the Appendix, which shows that our insider sample has fewer micro-cap stocks (smallest decile) and roughly twice the percentage of largest decile stocks as compared to the CRSP universe. Panel B of Table I shows that the insiders we include in our sample have a somewhat higher average number of trades (4.8 buys to 2.4 , and 8.2 sells to 4.1) relative to all insiders. ${ }^{12}$ All of these differences are statistically significant.

[Insert Table I here] 
However, we have verified that our sample is representative of the larger universe of all insider trades in terms of the percentage of insider buys and sells ( $24 \%$ buys in the entire sample, $25 \%$ in our sample) and in terms of the overall return predictability of insider buys and insider sells. For example, the difference in profitability of a valueweighted long-short portfolio that goes long insider buys and short insider sells, in our sample versus the overall sample, is only 21 basis points per month and is statistically insignificant $(t=0.83)$. Table A2 in the Appendix presents further evidence on the profitability of insider trades, by splitting the insider universe into young versus old companies (where the cutoff for young companies is 3 years since the IPO). Table A2 shows that there is no statistical difference in the profitability of insider trades in young versus old companies; thus we are not imposing any bias in our sample by focusing more often on insider trades made in large companies (that tend to be older). We also show (in Table A3 in the Appendix) that there is no statistical difference in the profitability of "young" versus "old" insiders (where youth is measured by years of trading history for a given insider--"old" insiders are those with more than 3 years of trading history).

We have also directly examined the set of "non-classified" trades, i.e. those trades that do not make it into universe, to check if these trades are systematically different from the trades in our universe. Non-classified trades consist of those insider trades that we cannot classify into either routine or opportunistic trades, since they were made by insiders without three consecutive years of past trading history. When we look at the properties of the entire non-classified universe, we see that these trades 
look similar to the trades in our universe. For example, in Appendix Table A4 we show that the returns on a naïve insider mimicking portfolio (buys-sells) in our universe compared to the returns on this same naïve insider mimicking portfolio in the currently non-classified universe are not statistically or economically different from one another. Further, Appendix Table A5 shows that if we run our baseline tests from Table II, but include all non-classified trades in either the opportunistic or routine category, opportunistic trades are still large and significant predictors of future returns, while routine trades are not. If anything, this table indicates that non-classified trades appear to more closely resemble opportunistic trades than routine trades, since the predictability of routine trades slightly improves once the non-classified trades are included in the routine category.

As Table I shows, in our sample we classify roughly $64 \%$ of insider purchases and $52 \%$ of insider sales as routine trades; hence $36 \%$ of insider purchases and $48 \%$ of insider sales are classified as opportunistic trades. Overall, trades made by routine traders comprise $55 \%$ of the total sample, while trades made by opportunistic traders represent $45 \%$ of the total sample.

In Appendix Table A6 we present the full set of correlation coefficients for the main variables that feature in our analysis. To summarize, we find that the number of opportunistic buys, number of opportunistic sells, number of routine buys, and number of routine sells are all essentially uncorrelated with each other. Additionally, the number of insider sells, and particularly routine sells, is higher for larger firms and 
growth firms, while the number of insider buys, and particularly opportunistic buys, is higher for smaller firms and value firms. Consistent with the past literature, insiders are contrarian, buying after low past returns (measured over the prior 12 months) and selling after high past returns.

\section{Performance of Opportunistic Versus Routine Insiders}

In this section we examine the future stock return predictability of corporate insiders. The goal of our approach is to identify, out of the hundreds of thousands of insider trades made each year, which trades are truly informative. To do so we implement our routine vs. opportunistic trader classification, and then analyze the stock return performance of routine versus opportunistic insiders.

\section{A. Baseline Regression Results}

Our first tests employ regressions of one-month-ahead stock returns on indicators for routine and opportunistic trades. We run pooled regressions with standard errors clustered at the firm level; we also include month fixed effects where indicated. In addition, we include controls for well-known determinants of stock returns, such as size

(log of market capitalization), (log) book-to-market ratio, one-month lagged returns, and cumulative past returns from month $t-12$ to $t-2$.

Table II presents these regression results. Columns 2 and 4 illustrate the main result of the paper: both opportunistic buys and opportunistic sells are strong predictors 
of future returns, while routine buys and sells are not. For example, the coefficient on opportunistic buys in column 2 indicates that opportunistic buys yield an incremental 90 basis points $(t=4.64)$ in the following month relative to all insider trades. Meanwhile, routine buys yield only 14 additional basis points $(t=0.81)$. The difference in the coefficients on opportunistic buys and routine buys ( $=76$ basis points) is statistically significant $(\mathrm{F}$-test $=10.07, \mathrm{p}$-value $=0.002) .{ }^{13}$ The results for sells are similar: Column 4 shows that opportunistic sells earn an additional -78 basis points $(t=5.67)$, while routine sells earn +4 additional basis points $(t=0.24)$. Again, this difference between opportunistic sells and routine sells is large (=-82 basis points) and statistically significant $($ F-test $=29.30$, p-value $=0.000)$.

Columns 5 and 6 of Table II present similar results, but with all four dummy variables (Opportunistic Buy, Routine Buy, Opportunistic Sell, Routine Sell) included in the same regression. Consistent with the results in Columns 1-6, these tests indicate that opportunistic trades are informative for future returns, while routine trades are not. In Column 6, the difference in coefficients between opportunistic buys and routine buys is 77 basis points ( $\mathrm{F}$-tests $=10.32$, p-value $=0.001$ ), and the difference in coefficients between opportunistic sells and routine sells is 81 basis points (F-test=28.87, pvalue $=0.000)$.

[Insert Table II here] 
Overall, the combined differences in the coefficients between opportunistic trades and routine trades in Table II translate into an increase of 158 basis points per month in the predictive ability of opportunistic trades relative to routine trades. ${ }^{14}$ Additionally, our results demonstrate that over half the improvement in predictive power gained by focusing on opportunistic trades comes from the superior performance of opportunistic sells relative to routine sells; as noted earlier, this is in contrast to much of the literature (e.g., Jeng et al. (2003)), which often struggles to find evidence that insider sales predict lower future returns.

\section{B. Trade-Level Results}

Next we investigate an alternate, trade-level measure of "routine" and "opportunistic," as opposed to the trader-level measure used so far. This measure allows a given trader to have both routine and opportunistic trades; e.g., a given trader may be dubbed routine after having three straight January trades, but in this alternate setup we only dub his subsequent January trades as routine trades, and categorize his trades in all other months as opportunistic. And also, an opportunistic trader can have routine trades if he establishes a routine in any given calendar month.

We present these trade-level results in Table III. Column 2 shows that the spread between opportunistic and routine buys using this trade-level measure (analog of Column 2 in Table II) is again large and significant ( $=94$ basis points, F-test $=8.39$, pvalue $=0.0038$ ), while Column 4 indicates that the spread between opportunistic and 
routine sells (analog of Column 4 in Table II) is also again large and significant $(=94$ basis points, $\mathrm{F}$-test $=15.99$, $\mathrm{p}$-value $=0.0001)$. These results demonstrate that our opportunistic vs. routine identification of informed insider trading is robust to reasonable changes in the classification procedure.

\section{[Insert Table III here]}

\section{Portfolio Returns}

In this section we analyze the returns of portfolios formed according to our routine trade classification scheme. These provide a further test of the predictive ability of opportunistic versus routine trades. To construct our portfolios, we identify opportunistic and routine trades each month, and then form opportunistic buy, opportunistic sell, routine buy, and routine sell portfolios containing these stocks. We then hold these stocks over the month following these insider trades; at the end of the month, we rebalance the portfolios based on new insider trades.

Although the official SEC regulation was a requirement to report by the tenth day of the following month (which was then changed to 2 days after the trade date in 2002), nearly all of the trades in our sample were reported to the SEC within a few days of the trade (median of 3 days over the entire sample), so we are confident they were available at portfolio formation here. Given that the actual required reporting date for insiders was the 10th of the following month until 2002, in the Appendix Table A7 we 
re-run all the results from Table II, but this time using returns from the 11th day of month $t+1$ to the 10th day of month $t+2$ in our tests (rather than from the 1st day of month $t+1$ to the last day of month $t+1$ ), and the results are virtually identical to those in Table II, meaning that our results are not sensitive to the timing convention we employ here; this finding also demonstrates that our results are fully tradable in realtime.

Table IV reports raw portfolio returns, as well as risk-adjusted portfolio returns (alphas) for the CAPM, Fama-French three-factor model, the Carhart (1997) four-factor model, and the five-factor model including a liquidity factor, as well as DGTW characteristic-adjusted returns. ${ }^{15}$ This table also reports both equal- and value-weighted portfolios. Table IV shows that a portfolio strategy that focuses solely on the trades made by opportunistic traders earns large and significant returns, while a strategy that follows the trades of routine traders does not. For example, the equal-weighted portfolio that goes long opportunistic buys and short opportunistic sells earns a five-factor alpha of 180 basis points per month $(t=6.07)$, or over $21.6 \%$ per year, while the portfolio that goes long routine buys and short routine sells earns a only marginally significant 43 basis points per month $(t=1.73)$.

[Insert Table IV here]

The bottom half of Table IV reveals a similar pattern for value-weighted returns. 
While the spread between routine buys and routine sells is actually negative when using value-weighted returns, the spread in five-factor alphas between opportunistic buys and opportunistic sells is a positive and significant 82 basis points per month $(t=2.15)$, or $9.8 \%$ per year. Thus our predictability evidence is not limited to smaller firms, as in some prior studies that use insider trading data (see Lakonishok and Lee (2001)). ${ }^{16}$ Further, these results again demonstrate that all of the return predictability in the insider universe is concentrated within the trades of opportunistic traders.

In Figure 1 we plot event-time returns based on the portfolios out to twelve months, to illustrate the longer-term performance of opportunistic trades relative to routine trades. Figure 1 indicates that the twelve-month event-time return on a valueweighted four-leg spread portfolio (=[Opportunistic Buy-Opportunistic Sells]-[Routine Buys-Routine Sells]) is roughly $4 \%$; for the equal-weighted four-leg spread portfolio, the twelve-month event-time return is roughly $8 \%$. In both cases, returns continue to rise for the first six months, and then level off, exhibiting no future reversal. The fact that we see no reversal following the price rise suggests that the information being conveyed through the trades of opportunistic insiders is important for fundamental firm value.

[Insert Figure 1 here]

Taken as a whole, the findings in Table IV and Figure 1 corroborate our earlier regression results, and provide economically and statistically significant evidence that 
insider trades by opportunistic traders are much more informative than insider trades by routine traders.

\section{Robustness}

In this section we perform a series of additional tests in order to evaluate the robustness of our findings. First we investigate the impact that the number of a given type of trade (i.e., the strength of the signal) may convey in terms of incremental information above and beyond the mere knowledge that a particular type of trade took place. These results are reported in Appendix Table A9. We find that the number of opportunistic buys (sells) is a strong predictor of future positive (negative) returns. To get an idea of the magnitude of this effect, a one-standard deviation increase in the log number of opportunistic buys per month translates to higher future returns of 35 basis points per month $(t=4.56) .{ }^{17}$ In contrast, the number of routine buys and the number of routine sells have no relation to future returns.

We also verify that our results are not concentrated on a particular exchange, in certain types of stocks, or at certain specific times. To do so, we examine a variety of subsamples, such as NYSE stocks versus Nasdaq stocks, large stocks versus small stocks, stocks heavily-traded by insiders versus stocks lightly-traded by insiders, and finally trades made only during specific times (such as inside or outside explicit "blackout" windows).

Appendix Table A10 presents our results broken down by exchange listing, and 
shows that opportunistic buys and sells are strong predictors of future returns for both NYSE and Nasdaq stocks, while routine buys and sells are uninformative across both exchanges. In Appendix Table A11, we find that opportunistic trades (both buys and sells) predict returns for both large stocks and small stocks, while routine trades (both buys and sells) are uninformative for both large and small stocks. To check if insider trading intensity (see Seyhun (1998) and Lakonishok and Lee (2001)) is related to our findings, we split our sample by the fraction of shares outstanding traded by insiders in the prior year for a given stock, and again find that both opportunistic buys and sells are strongly predictive of future returns for both high- and low-intensity stocks.

We also explore if our results are concentrated inside (or outside) explicit "blackout" windows, which are times during which insiders are allegedly prohibited from trading in their company's stock. Although these windows vary by firm (see Bettis, Coles, and Lemmon (2000)), many firms explicitly allow insider trading solely during the month following a quarterly earnings announcement (e.g., trading days +3 to +24 after an earnings release). Focusing on the post-earnings $(+3$ to +24$)$ trading window, and also excluding any trades that occur up to 30 days before an M\&A announcement, in order to define our "non-blackout" period, ${ }^{18}$ we find that during both blackout and non-blackout periods, opportunistic buys (and sells) are strong predictors of future returns. In contrast, routine trades (buys and sells) have no predictive power for future returns during either blackout or non-blackout periods. Thus our robustness checks indicate that opportunistic trades are much more informative than routine trades for a 
variety of subsamples: NYSE stocks, Nasdaq stocks, large stocks, small stocks, heavilytraded stocks, lightly-traded stocks, and inside and outside pre-defined blackout windows.

Taken as a whole, our results indicate that opportunistic trades, and the intensity of these trades, are a robust predictor of future returns, while routine trades are not. These findings suggest that the ability to predictably classify insiders into either routine or opportunistic traders, using our simple empirical strategy, allows one to focus in on the half of the insider universe that contains all the informative trades.

\section{What Insiders Predict and Who Mimics Their Trades}

In this section we explore the mechanism behind the large return predictability that we observe following opportunistic insider trades, and also explore the link between institutional trading and opportunistic insider trading.

\section{A. Predicting Firm-Level Information Events}

We start by examining whether opportunistic traders are more likely than routine traders to trade preceding important information events for the firm. To do so, we run panel regressions of firm-level information events (available from 1989-2000) on the number of opportunistic trades and the number of routine trades. The information events we examine are: headline news events about the firm, sell-side analyst research releases about the firm (i.e., annual and quarterly earnings forecast revisions, as well as 
buy/sell recommendation changes), and important management disclosures about the firm (SEO announcements and merger announcements). ${ }^{19}$ We use the number of firmlevel information events in a given category in a given month as our left-hand side variable, and control for the general level of news about the firm on the right-hand side (using, for example, the number of information events last month, and the average number of information events over the prior six months). As in Tables II and III, we also control for firm-level measures of size, book-to-market, and past returns.

Table V shows that opportunistic trades are predictive of future information events at the insider's firm, while routine trades are not. This result holds across all information events, holds for a variety of sub-categories, and holds whether or not we control for the general level of news about a firm. For example, in Column 2 of Table $\mathrm{V}$, where we use the sum of all information events as the left-hand side variable, the coefficient on the number of opportunistic trades is positive $(=0.03)$ and significant $(t=2.78)$, while this same coefficient for routine trades is insignificant. To get an idea of the magnitude of this effect, a one-standard deviation increase in the number of opportunistic trades translates into 1.0 more total information events in the following month for the firm; the average number of total information events per firm per month is 4.8 (median=5), so this effect implies a percentage increase of around $20 \%$ in the number of important events following these opportunistic trades.

[Insert Table V here] 
Looking specifically at firm news, Columns 3 and 4 show that opportunistic insider trades are strongly predictive of future headline news events. The coefficient on opportunistic trades in Column $4(=0.03, t=3.26)$ implies that for a one-standard deviation move in the number of opportunistic trades, the firm experiences 1.0 more headline news events next month relative to an average of 3.3 events per month (median $=3)$; in percentage terms this translates to a $32 \%$ to $35 \%$ increase in the number of headline news events. Finally, in the Appendix Table A12 we show that if we split the number of opportunistic insider trades into the number of opportunistic buys and sells separately, both variables predict future news. In fact, Column 6 of Table A12 indicates that opportunistic sells have somewhat more predictive power for future news than opportunistic buys, although both are significant predictors of future news. This provides additional evidence on the power of our classification scheme to identify informative insider sells in particular, in contrast to much of the literature.

\section{B. Predicting Announcement Returns for Specific Types of News Releases}

In this section we explore in greater detail the specific types of news events that follow opportunistic trading. Exploring this issue in greater depth gives more insight into the source of insider profitability. To do so, we examine the predictability of opportunistic buys and sells for announcement returns for a series of news categories.

In general, we find that opportunistic trades seem to predict shorter-term news 
events, as opposed to long-term firm-level measures like annual employment or inventory changes. For example, Table VI reports the results of regressions of announcement returns (from $t-1: t+1$ ), for various types of events, on opportunistic and routine insider trades. Focusing first on headline news events as the dependent variable (in Column 1), we see that opportunistic buys in the prior month predict higher news announcement returns (coefficient $=0.29, t=2.59$ ), and opportunistic sells in the prior month predict lower news announcement returns (coefficient $=-0.22, t=4.11$ ). At the same time, routine buys and routine sells have no predictive power for news announcement returns (and the signs are actually in the opposite direction from the opportunistic trade coefficients).

\section{[Insert Table VI here]}

Next we explore specific kinds of news releases, and find that opportunistic trades (primarily opportunistic buys) predict analyst information releases (recommendations + earnings forecasts), analyst earnings forecasts by themselves, management forecasts, and firm-level earnings announcements. Specifically, Columns 2-5 of Table VI show that opportunistic buys in the prior month have statistically significant predictive power for announcement returns around analyst information events (coefficient $=0.13, t=1.78$ ), earnings forecasts (coefficient $=0.17, t=2.17$ ), management forecasts $($ coefficient $=1.05$, $t=2.46$ ), and future earnings announcement returns (coefficient $=0.30, t=1.96$ ). For all 
of these regressions, opportunistic sells do not have statistically significant predictive power for future announcement returns, although the signs are all negative. Meanwhile, routine trades are never significant predictors of future announcement returns across all event categories, except in the case of routine sells predicting positive earnings announcement returns.

In untabulated tests we also examine mergers and issuance in this same framework, but find that neither routine trades nor opportunistic trades have predictive power for merger/issuance announcement returns in the following month. And lastly, in addition to these relatively high-frequency announcement return tests, we also examine some annual variables such as employment and inventory changes (drawn from Compustat), finding little evidence that insider trading (by either opportunistic or routine insiders) predicts these lower-frequency, annual variables.

\section{The Link Between Institutional Trading and Opportunistic Trading}

Our results on the predictive ability of opportunistic insiders' trades raise the question of whether or not other investors or agents in the financial markets are aware of this type of informed trading. In this section of the paper we explore the connection between institutional trading and opportunistic insider trading, and later in the paper we explore the link between SEC activity and opportunistic insider trading.

To investigate a potential link between institutional trading and opportunistic insider trading, we regress the change in institutional ownership of a stock on the (log of 
the) number of opportunistic and routine trades in that stock. We measure the change in institutional ownership at a quarterly frequency, and aggregate up the number of opportunistic/routine trades each quarter as well. We explore both a lagged response (i.e., the impact of opportunistic/routine trades over the past 2 quarters on the change in institutional holdings this quarter), and a contemporaneous response (i.e., the impact of opportunistic/routine trades this quarter on the change in institutional holdings this quarter).

This approach enables us to tackle two questions. The lagged response allows us to answer the following question: do institutions follow the trades of opportunistic insiders in their subsequent trades? And the contemporaneous response allows us to answer a slightly different question: do institutions provide differential liquidity for some types of insider trades relative to others (i.e., are institutions smart enough to provide liquidity only in the case of routine trades). Our tests are similar in spirit to those performed in Sias and Whidbee (2010), who report a strong inverse relation between insider trading and institutional demand in the same quarter and over the previous year.

The last three columns of Table VI present the results of these tests. We find some suggestive evidence on both of the questions posed above. First, we find that institutions do appear to react more strongly to past opportunistic trades than to past routine trades. Past opportunistic buys (sells) predict future increases (decreases) in institutional holdings, meaning that institutions trade in the same direction as past 
opportunistic insiders. Further, Column 8 of Table VI shows that the predictive power of opportunistic buys for future holdings is statistically significant even after including controls for size, book-to-market, and previous year returns, as well as date fixed effects (coefficient $=0.167, t=2.13$ ). The predictive power of opportunistic sells for future holdings is statistically significant without fixed effects and controls, marginally significant with fixed effects, but not significant with fixed effects and controls (although the sign is still negative). Meanwhile, routine buys predict future increases in institutional holdings, but this result is smaller in magnitude than the predictive power of opportunistic buys, and is not statistically significant with fixed effects and controls included. Column 8 also shows that routine sells predict changes in holdings with the opposite sign (the coefficient is positive); plus the result is not statistically significant. Taken together, these findings provide suggestive evidence that institutions follow opportunistic insiders' trades (particularly the opportunistic buys) more so than routine insiders' trades. Thus institutions do appear to have at least some understanding of the differential informativeness of opportunistic versus routine insider trades that we document in this paper.

Second, in looking at the contemporaneous responses (i.e., the impact of opportunistic/routine trades this quarter on the change in institutional holdings this quarter), we find some modest evidence that institutions appear to provide liquidity for routine buys, but not for (or at least less for) opportunistic buys. Specifically, in Columns 6-8 of Table VI the coefficient on contemporaneous routine buys is negative 
and significant, but the coefficient on contemporaneous opportunistic buys is insignificant and only slightly negative. Meanwhile the coefficients on both opportunistic sells and routine sells are both insignificant.

Collectively, these tests highlight a potential link between institutional trading and insider trading. While our evidence is only suggestive, our results are consistent with the idea that institutions follow the trades of past opportunistic insider trades (particularly opportunistic buys), and also provide liquidity to contemporaneous routine buys.

\section{Which Insiders Are Informed?}

Next we explore our basic results in even greater depth by analyzing which types of opportunistic insiders are especially informed about future news events.

\section{A. Who Predicts News?}

To isolate the types of insiders who are most informed, we run predictive regressions of news on various categories of insiders. Specifically, in Table VII we add a series of additional explanatory variables to the specifications from Columns 1-3 of Table V, where we use the total number of information events as our dependent variable. In addition to the number of opportunistic trades, we add independent variables equal to: a) the number of opportunistic trades by local insiders (where local is 
defined as residing in the same state as the firm's corporate headquarters), b) the number of opportunistic trades by senior insiders (where senior is defined as either the CEO, CFO, or Chairman of the Board), c) the number of opportunistic trades by inside/non-independent directors ${ }^{20}$ and d) the number of opportunistic trades by outside/independent directors (where independent directors are identified using the "role-code" variable in the Thomson database). ${ }^{21}$

The first column of Table VII indicates that the number of opportunistic trades by local insiders is positively related to the total number of firm-level information events in the following month. The magnitude of the coefficient in Column $1(=0.03, t=2.85)$ implies that for a one-standard deviation move in the number of opportunistic trades by locals, the firm experiences 1.0 additional information events next month (so a roughly $20 \%$ increase, with an average of 4.8 and median of 5). By contrast, comparing these to the opportunistic trades of the other classes of insiders in Columns 2-4, and especially in the full specification of Column 5, we find no significant difference in the explanatory power between the opportunistic trades of independent directors, senior insiders, or inside directors. Given the evidence in Ravina and Sapienza (2009) that the difference in the profitability of insider trades by executives relative to those by independent directors is quite small, these results may not be surprising. Geographic localness of the opportunistic insider, in contrast, remains a strong, significant predictor.

\section{[Insert Table VII here]}




\section{B. The Characteristics of Informed Insiders}

An intriguing finding from Table VII is that it is specifically the local insiders who are not senior management whose opportunistic trades predict future information events. In this section we explore this finding in greater depth to try to better understand the characteristics of these insiders. To do so, we run a logit regression that tries to pinpoint the characteristics of these local non-senior insiders, where the dependent variable equals 1 if the insider in question is a local non-senior opportunistic trader, and where the independent variables are a series of insider- and firm-level characteristics. We explore the following independent variables: a) the tenure of the insider at the given firm, b) firm-level geographic concentration, c) firm-level governance, and d) firm-level products. Insider experience is measured as the (log of the) number of years active as an insider for the given firm. To measure firm-level geographic concentration, we employ three measures using on the dispersion of each firm's operations across states. Specifically, we use data from Garcia and Norli (2010) on the state-level operations of public firms. ${ }^{22}$ This data is much more detailed than the Compustat Geographic Segment Data, which only provides coarse segment data on whether or not the firm was completely domestic versus having some segments located internationally. We construct three measures: i) the percentage of sales in a firm's home (local) state, ii) a geographic Herfindahl index using sales and drawn from this same data, and iii) the (log of the) number of states that the firm has operations in. 
We measure firm-level governance using the value of the G-Index from Gompers, Ishii, Metrick (2003). Finally, we compute firm-level products using data from the Compustat segment file, and use the number of products for a given firm in a given year in our regression tests. Note that each insider, and so each independent variable, is defined when the insider is labeled as routine or opportunistic (after the insider trades three years in a row for the first time, in December of the third year with trades).

Table VIII presents the results from these tests. Table VIII indicates that local non-senior opportunistic insiders are more likely to be: a) those with longer tenure at the firm, b) those from more geographically concentrated firms, c) those from poorly governed firms, and d) those from firms that make more products. Specifically, Column 1 shows that the coefficient on $\log$ (number of years active) is positive and significant in predicting the likelihood of becoming a local non-senior opportunistic trader. We control for the number of trades in this regression, as we want to isolate the effect of time in the firm, conditional on trading activity of the individual insider (so for two insiders that have traded the same amount, is the one who has had longer to build the firm relationship more likely to be the informed opportunistic insider). Level of trading itself is a negative and significant predictor of being a local non-senior insider who trades opportunistically. This is consistent with routine insiders simply trading every routine period irrespective of information, while these informed local non-senior opportunistic traders trade only when they have valuable information (perhaps not surprisingly, less frequently). ${ }^{23}$ 
[Insert Table VIII here]

Columns 2-4 show that for all three measures of geographic concentration, the more geographically concentrated a firm is, the more likely the insider is to be a local non-senior who trades opportunistically. Specifically, Columns 2, 3, and 4 show respectively that: the fewer states a firm operates in, the more geographically concentrated firm operations are, and the larger the percentage of operations in the home (local to the insider) state, the more likely the insider is to be one of these informed local insiders. Next, Columns 5 and 6 show that coming from a poorly governed firm (measured using the value of the G-Index from Gompers, Ishii, Metrick (2003), where larger numbers signify worse governance, and also using a dummy variable equal to 1 if the firm has a G-Index $>12$ - which is the $90^{\text {th }}$ percentile in our sample) is a positive and significant predictor of become a local non-senior opportunistic trader in our sample. Finally, Column 7 indicates that a measure of firm-level products is a positive predictor of the likelihood of becoming a local non-senior insider.

Taken as a whole, our results on the characteristics of these local, non-senior opportunistic insiders are interesting, and intuitive. For example, the idea that one's tenure at a company would be correlated with one's level of information about that company is sensible, as is the fact that local non-senior opportunistic traders would be more likely to come from geographically concentrated firms. The product result is 
novel, and suggests that firms that produce lots of products, many of which may be hard to evaluate from the outside, tend to be places where the marginal benefit of inside information is largest. And finally, the governance result is consistent with the idea that informative insider trading is more likely to take place where monitoring and institutional controls are weaker.

\section{SEC Activity and Opportunistic Insider Trading}

As noted earlier, our results on the predictive ability of opportunistic insiders' trades raise the question of whether or not other agents in the financial markets are aware of this type of informed trading, particularly the key enforcement agency responsible for prosecuting illegal insider trading: the SEC. While we cannot say definitively that our tests pinpoint illegal insider trading, we do note that: a) several high-profile insiders who were later charged by the SEC (e.g., Kenneth Lay (Founder and Chairman of Enron), Jeff Skilling (CEO of Enron), Joseph Nacchio (CEO of Qwest Communications), Victor Menezes (Senior Vice Chairman of Citigroup), and David Willey (CFO of Capital One)) are classified as opportunistic insiders according to our classification scheme, and b) our earlier results that opportunistic trades predict future news, returns at the time of the news, and earnings announcement returns, suggest that some of these insiders may be trading on material, non-public information. In this section, we explore the link between SEC activity and opportunistic insider trading more formally. 


\section{A. The Response of Opportunistic Insiders to SEC Activity}

First we explore the behavior of opportunistic traders in the wake of news about illegal insider trading litigation cases. Since opportunistic trades predict future firmlevel returns, as well as future firm-level news, it is plausible that opportunistic traders might be especially sensitive to the potential costs and penalties associated with illegal insider trading. We test this idea by regressing the fraction of insiders trading in a given month who are opportunistic on recent SEC releases regarding litigation cases against illegal insider trading. Specifically, the dependent variable we examine is the number of opportunistic insiders trading in month $t+1$ divided by the number of all insiders trading in month $t+1$, and the independent variable of interest is the natural logarithm of one plus the number of SEC releases regarding litigation cases against illegal insider activity in month $t$. We include control variables for the fraction of opportunistic insiders trading in month $t$ and month $t-1$, the CRSP value-weighted market return in month $t$, the standard deviation of daily market returns in month $t$, and various windows of past cumulative market returns (month $t-3$ to $t-1$, month $t-6$ to $t-1$, and month $t-12$ to $t-1)$.

Panel A of Table IX illustrates that opportunistic trading decreases significantly following recent releases from the SEC regarding illegal insider trading cases, consistent with the idea that opportunistic traders dampen their trading activity when the potential costs of illegal trading increase. Specifically, the coefficient on the number of 
SEC releases in Column 7 is $-0.015(t=2.41) .^{24}$

[Insert Table IX here]

\section{B. What Predicts SEC Investigations?}

Next we analyze the determinants of being investigated by the SEC in a regression framework in Panel B of Table IX. Specifically, Panel B reports logit regressions, where the dependent variable is equal to one if the insider has been named in an SEC press release related to insider trading. The observations are at the insider level, and insider characteristics are recorded based on all trades of each insider. The independent variable of interest is the number of opportunistic trades each insider has in our sample; we also explore an indicator variable that takes the value of one for opportunistic insiders and zero otherwise.

Column 1 of Panel B shows that while simply being opportunistic increases the likelihood of SEC investigation (and is marginally significant), the number of trades seems to be a statistically stronger predictor. However, this hides interesting variation, as in Column 2 we split this number of trades into its two components: number of opportunistic and number of routine trades. Column 2 of Panel B indicates that the number of opportunistic trades is a positive and significant predictor of the likelihood of being investigated by the SEC, while the number of routine trades is not. In other words, insider trading that reliably predicts future SEC action is opportunistic, not 
routine, trading. In terms of magnitude, we find that opportunistic trading roughly doubles the likelihood of investigation (a one-standard deviation move in opportunistic trades increases the probability of investigation to $0.08 \%$, up from $0.04 \%$ ). This increase is small in an absolute sense, given the small absolute number of enforcement actions taken by the SEC. Column 3 indicates that the share of opportunistic trades is also a significant predictor of future investigations. Finally, Column 4 shows that it is specifically the number of opportunistic sells that increases the likelihood of a future SEC investigation, again highlighting the power of our classification scheme to specifically identify informative insider sells, in contrast to much of the literature.

Collectively these results suggest an interesting, and coherent, link between SEC activity and opportunistic trading. Since opportunistic trades are a significant predictor of the likelihood of being investigated by the SEC, it is not surprising that opportunistic trading decreases significantly following recent releases from the SEC regarding illegal insider trading cases, consistent with the idea that opportunistic traders dampen their trading activity when the potential costs of illegal trading increase.

\section{Conclusion}

In this paper we employ a simple empirical strategy to decode the information in insider trading. Our analysis rests on the basic premise that insiders, while possessing private information, trade for many reasons, and that by identifying ex-ante those insiders whose trades are "routine" (and hence uninformative), one can better isolate 
the true information that insiders contain about the future of firms. Using simple definitions of routine traders, we are able to systematically and predictably identify insiders as either opportunistic or routine throughout our sample. We show that stripping away the uninformative signals of routine traders leaves a set of informationrich opportunistic trades that are powerful predictors of future firm returns, news, and events.

We show that while the abnormal returns associated with routine traders are essentially zero, a portfolio strategy that instead focuses solely on opportunistic insider trades yields value-weighted (equal-weighted) abnormal returns of 82 basis points per month (180 basis points per month). Similarly, in a regression context the combined differences in the coefficients between opportunistic trades and routine trades translate into an increase of 158 basis points per month in the predictive ability of opportunistic trades relative to routine trades. Further, this effect increases with the strength of the opportunistic signal (as measured by the number of trades or trade-size intensity), but is unrelated to the strength of the routine signal.

In exploring the mechanism at work behind our identification and return results, we demonstrate that trades by opportunistic insiders predict future firm news and future firm events, while trades by routine insiders do not. Opportunistic traders have particular predictive ability for the information in future firm-level announcements such as earnings forecasts and managerial forecasts. The most informed opportunistic traders tend to be local non-senior opportunistic insiders, and these traders are likely to come 
from geographically concentrated firms and poorly governed firms.

Further, we find that opportunistic trading increases the likelihood of SEC enforcement against insiders (while routine trading has no impact). Also, opportunistic traders decrease their trading activity in the wake of increases in the number of news releases by the SEC regarding illegal insider trading cases, consistent with the idea that opportunistic traders are sensitive to the potential costs of illegal insider trading. Finally, we find suggestive evidence that institutional investors mimic the trading of opportunistic (but not routine) traders, and yet provide contemporaneous liquidity to (less informative) routine traders.

Collectively our results suggest that it is possible to identify, out of the hundreds of thousands of investors who trade in the market each year, which traders are truly informed. More generally, decoding the true information in other activities in the market, such as the trades made by banks or institutional investors, may also be a promising avenue. These insights could allow us to understand new characteristics of other informed financial agents and the exact type of information these informed agents possess, which would help investors, market regulators, and all active participants in securities markets develop a clearer picture of the information environment that helps form asset prices. 


\section{References}

Bettis, Carr, Jeffrey Coles, and Michael Lemmon, 2000, Corporate policies restricting trading by insiders, Journal of Financial Economics 57, 191-220.

Bettis, Carr, Don Vickery, and Donn W. Vickery, 1997, Mimickers of corporate insiders who make large-volume trades, Financial Analysts Journal 53, $57-66$.

Clarke, Jonathan, Craig Dunbar, and Kathleen M. Kahle, 2001, Long-run performance and insider trading in completed and canceled seasoned equity offerings, Journal of Financial and Quantitative Analysis 36, 415-430.

Daniel, Kent, and Sheridan Titman, 1997, Evidence on the characteristics of cross sectional variation in stock returns, Journal of Finance 52, 1-33.

Daniel, Kent, and Sheridan Titman, 1998, Characteristics or covariances?, Journal of Portfolio Management 24, 24-33.

Daniel, Kent, Mark Grinblatt, Sheridan Titman, and Russ Wermers, 1997, Measuring mutual fund performance with characteristic-based benchmarks. Journal of Finance 52, 1035-1058.

Garcia, Diego, and Oyvind Norli, 2010, Geographic dispersion and stock returns, Working paper, University of North Carolina - Chapel Hill.

Elliot, John, Dale Morse, and Gordon Richardson, 1984, The association between insider trading and information announcements, Rand Journal of Economics 15, 521-536.

Fernandes, Nuno, and Miguel Ferreira, 2009, Insider trading laws and stock price informativeness, Review of Financial Studies 22, 1845-1887.

Fidrmuc, Jana, Marc Goergen, and Luc Renneboog, 2006, Insider trading, news releases and ownership concentration, Journal of Finance 61, 2931-2973.

Henderson, M. Todd, Alan Jagolinzer, and Karl Muller, 2010, Strategic disclosure of 10b5-1 trading plans, Working paper, University of Chicago. 
Jaffe, Jeffrey, 1974, Special information and insider trading, Journal of Business $47,410-428$.

Jagolinzer, Alan, 2009, SEC Rule 10b5-1 and insiders' strategic trade, Management Science 55, 224-239.

Jeng, Leslie, Andrew Metrick, and Richard Zeckhauser, 2003, Estimating the returns to insider trading: a performance-evaluation perspective, The Review of Economics and Statistic 85, 453-471.

Jenter, Dirk, 2005, Market timing and managerial portfolio decisions, Journal of Finance 60, 1903-1949.

Kahle, Kathleen, 2000, Insider trading and the long-run performance of new security issues, Journal of Corporate Finance 6, 25-53.

Ke, Bin, Steven Huddard, and Kathy Petroni, 2003, What insiders know about future earnings and how they use it: Evidence from insider trades, Journal of Accounting and Economics 35, 315-346.

Knewtson, Heather, Richard Sias, and David Whidbee, 2010, Style timing by insiders, Financial Analysts Journal 66, 46-66.

Lakonishok, Josef, and Inmoo Lee, 2001, Are insiders' trades more informative?, Review of Financial Studies 14, 79-111.

Lin, Ji-Chai, and John Howe, 1990, Insider trading in the OTC market, Journal of Finance 45, 1273-1284.

Lorie, James, and Victor Niederhoffer, 1968, Predictive and statistical properties of insider trading, Journal of Law and Economics 11, 35-53.

Marin, Jose, and Jacques Olivier, 2008, The dog that did not bark: Insider trading and crashes, Journal of Finance 63, 2429-2476.

Norton, Curtis, and Gary Porter, 2010, Financial Accounting: The Impact on Decision Makers, South Western Publishers.

Piotroski, Joseph, and Darren Roulstone, 2005, Do insider trades reflect contrarian beliefs and superior knowledge about cash flow realizations?, Journal of Accounting and Economics 39, 55-81. 
Ravina, Enrichetta, and Paola Sapienze, 2010, What do independent directors know? Evidence from their trading, Review of Financial Studies 23, 962-1003.

Rozeff, Michael, and Mir Zaman, 1988, Market efficiency and insider trading: New evidence, Journal of Business 61, 25-44.

Scott, James, and Peter $\mathrm{Xu}$, 2004, Some insider sales are positive signals, Financial Analysts Journal 60, 44-51.

Sen, Rik, 2008, Are pre-planned insider sales strategically timed?, Working paper, New York University.

Seyhun, H. Nejat, 1986, Insiders' profits, costs of trading, and market efficiency, Journal of Financial Economics 16, 189-212.

Seyhun, H. Nejat, 1988, The information content of aggregate insider trading, Journal of Business 61, 1-24.

Seyhun, H. Nejat, 1992, Why does aggregate insider trading predict future stock returns?, Quarterly Journal of Economics 107, 1303-1331.

Seyhun, H. Nejat, 1998, Investment Intelligence from Insider Trading, MIT Press, Cambridge, MA.

Sias, Richard, and David Whidbee, 2010, Insider trades and demand by institutional investors, Review of Financial Studies 23, 1544-1595. 
${ }^{1}$ From the U.S. Securities and Exchange Commission website: http://www.sec.gov/about/whatwedo.shtml\#intro.

${ }^{2}$ From the U.S. Securities and Exchange Commission website: http://www.sec.gov/about/whatwedo.shtml\#intro.

${ }^{3}$ The name of the firm, the insiders, and the dates involved, have been disguised.

${ }^{4}$ The Internet Appendix can be found at http://www.afajof.org/supplements.asp.

${ }^{5}$ A related strand of the literature studies insiders' ability to forecast the time series of aggregate stock returns (see, for example, Seyhun (1988, 1992, 1998) and Lakonishok and Lee (2001), among others), and the time-series variation in the value premium (see Knewtson, Sias, and Whidbee (2010)), subjects we do not explore in this paper. See also Fernandes and Ferreira (2009) for cross-country evidence on insider trading laws and stock price informativeness.

${ }^{6}$ See also Fidrmuc, Goergen, and Renneboog (2006), and Elliott, Morse, and Richardson (1984) for other evidence of insiders trading around news events.

${ }^{7}$ See also Sen (2008) and Henderson, Jagolinzer, and Mueller (2010) for more evidence on 10b5-1 plans.

${ }^{8}$ See Jeng et al. (2003) for details on data issues with Form 4.

${ }^{9}$ We have experimented with different back-windows (e.g., two, three, four, and five years) of past trading in the same calendar month. We find similar results in both magnitude and significance for all windows. We show the results using a three year 
back-window throughout the paper.

${ }^{10}$ For instance, in Appendix Table A1 we present results that employ a rolling-window approach that allows each insider to be reclassified each year based on the last three rolling years of data. This approach effectively allows each insider to switch back and forth between being an opportunistic and routine insider. Table A1 shows that both opportunistic buys and sells are large and significant predictors of future returns: from Column 3 the coefficient on opportunistic buys is $0.715(t=4.15)$, and from Column 6 the coefficient on opportunistic sells is $-0.605(t=4.30)$; meanwhile both routine buys and sells are uninformative for future returns.

${ }^{11}$ If we modify our approach with the goal of maximizing the number of insider trades that we capture in our tests, our results are unchanged. For example, by utilizing all transactions (e.g., options transactions) during the classification period in order to identify opportunistic/routine insiders, rather than just purchase/sale transactions as we do in the paper, and by including all trades that are currently in the classification period in the tests, we can capture over $76 \%$ of all insider trades (and $93 \%$ of firmmonths) in our return tests and obtain similar results: e.g., opportunistic buys predict future returns of 98 basis points per month $(t=12.25)$, and opportunistic sells predict future returns of -33 basis points per month $(t=4.61)$ using this modified approach.

${ }^{12}$ Note that the average number of trades listed here only includes trades made after we classify an insider as opportunistic or routine. All insiders in our sample have at least 
three more years worth of trades that we use to classify insiders, but that we do not use in our subsequent tests.

${ }^{13}$ The test of equality of routine and opportunistic coefficients is based on the point estimates and the robust covariance matrix of the estimates (clustered at the firm level). ${ }^{14}$ From column 6, the difference is 158 bp [ $=(57-(-20)-(-67-14)]$.

${ }^{15}$ Daniel and Titman $(1997,1998)$ suggest that characteristics can be better predictors of future returns than factor loadings. Following Daniel, Grinblatt, Titman, and Wermers (1997), we subtract from each stock return the return on a portfolio of firms matched on market equity, market-book, and prior one-year return quintiles (a total of 125 matching portfolios). These 125 portfolios are reformed every month based on the market equity, M/B ratio, and prior year return from the previous month. The portfolios are equal weighted and the quintiles are defined with respect to the entire CRSP universe in that month. We term these abnormal returns DGTW characteristicadjusted returns.

${ }^{16}$ We have also experimented with various "trade-weighted" portfolio returns, and these results are similar to those reported here. For instance, Appendix Table A8 employs three different portfolio weighting schemes: 1) weighting by dollar trade size (using "tprice," the self-reported transaction price), 2) weighting by dollar trade size (using CRSP end-of-day closing price for transaction price), and 3) weighting by percentage of shares outstanding. As Table A8 shows, all three weighting schemes yield similar 
results. The long-short (buys minus sells) opportunistic portfolio earns average abnormal returns ranging from 101 to 153 basis points per month (with t-stats ranging from 2.10 to 3.04 ), depending on the particular risk-adjustment and weighting scheme used. Meanwhile the long-short (buys minus sells) routine portfolio spread is much smaller in magnitude, and is always insignificant.

${ }^{17}$ Note that we have also run all tests in Tables II and A9 using Fama-MacBeth regressions, as well as pooled regressions with month and firm fixed effects, and the results are very similar. For instance, the analog of the full specification in Table A9, Column 9 using a Fama-MacBeth estimation gives buy and sell coefficients of 0.70 $(t=3.72)$ and $-0.40(t=-2.86)$, and using month and firm fixed effects gives coefficients of $0.56(t=2.46)$ and $-0.21(t=2.23)$.

${ }^{18}$ We have experimented with a variety of other definitions for blackout windows, and the results are similar to those presented here.

19 We exclude other firm events such as earnings announcements and dividend announcements that are often pre-scheduled far in advance and subject to explicit insider trading blackout periods.

${ }^{20}$ Note that not all insiders are necessarily directors. The class of insiders includes nondirectors, inside directors, and outside directors.

${ }^{21}$ We have also examined the characteristics of opportunistic versus routine traders in a logit framework. Their characteristics are, by and large, remarkably similar; e.g., the 
percentage of insiders that are local, independent, or senior, are not reliably different across the two groups.

${ }^{22}$ We thank Diego Garcia and Oyvind Norli for graciously providing their data on statelevel operations of firms.

${ }^{23}$ Again the independent variables in this table are measured at the end of each insider's classification period, which occurs the first time an insider trades for three straight years; we have variation in the number of years active because different insiders trade for a different number of years before they have a string of three consecutive years with a trade.

${ }^{24}$ Summary statistics for our litigation data are as follows: The average number of insider-trading-related press releases the SEC makes in a given month is 6.8 (median 6), with a standard deviation of $5.3\left(\max =36,75^{\text {th }}\right.$ percentile $=9,25^{\text {th }}$ percentile $\left.=3, \min =0\right)$. 


\section{Figure 1: Returns to Opportunistic Trades, Event-time Returns}

This figure shows the event-time returns to portfolios that follow the trades of opportunistic and routine insiders from 1989 to 2007 . Opportunistic trades are defined as in Table I, as are routine trades. This figure presents the difference in performance following opportunistic versus routine buys (dashed line), opportunistic versus routine sells (dotted line), and of the buy-sell, opportunistic-routine spread portfolio (solid line), over 12 months following portfolio formation.

Returns to Opportunistic and Routine Trades in the following 12 months

\section{Equal-weighted portfolios}

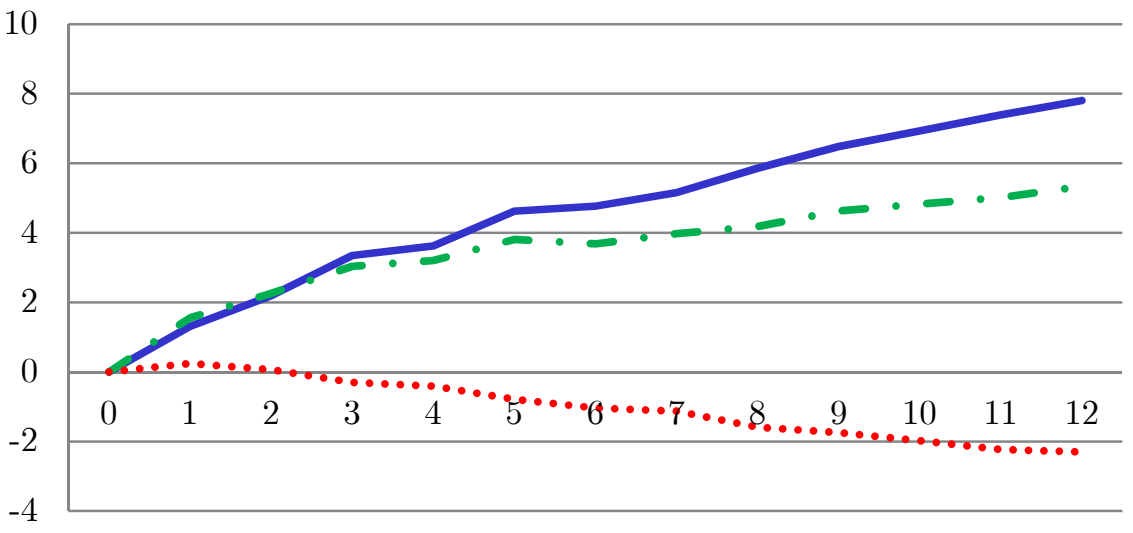

Opportunistic minus Routine (Buys - Sells)

- Opportunistic (Buys - Sells)

-.... Routine (Buys - Sells)

\section{Value-weighted portfolios}

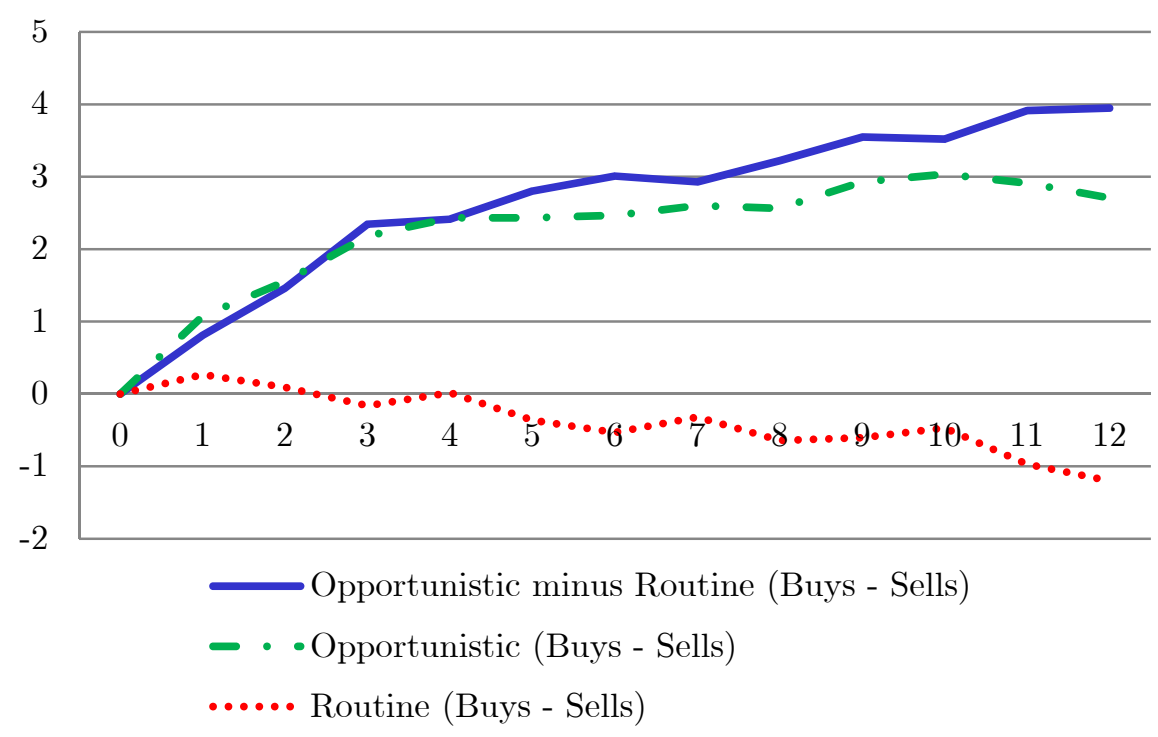




\section{Table I: Summary Statistics}

This table presents an overview of the sample we use in this paper, for which we can define programs (Partitionable Universe), compared to the entire TFN Insiders database (Insider Universe), between 1989 and 2007. Each year, the partitionable universe is that universe of insiders who have at least one trade in each of the preceding 3 years (so that routine traders and opportunistic traders can be defined). Panel A presents firm-level characteristics, with all numbers being full sample averages (medians), except for \# of unique companies, which is the total number of unique companies over the entire sample period. Size is defined as the market capitalization of the firm in millions of dollars. Book-to-markets that are negative, or greater than 100 (likely mistakes in the data) are excluded from the data. Panel B presents insiderlevel characteristics for both the Partitionable Universe and the Insider Universe. Trades over the last three years are used to characterize insiders as either routine or opportunistic traders. All subsequent trades that are made after we classify each insider as either routine or opportunistic are then placed into one of two buckets: a) "routine trades" (i.e., all trades made by routine traders), and b "opportunistic trades" (i.e., all trades made by opportunistic traders).

\begin{tabular}{|c|c|c|c|c|}
\hline \multicolumn{5}{|c|}{ Panel A: Firm-Level Characteristics } \\
\hline & \multicolumn{2}{|c|}{ Partitionable Universe } & \multicolumn{2}{|c|}{ Insider Universe } \\
\hline & Average & Median & Average & Median \\
\hline Size & 3274 & 330 & 1604 & 117 \\
\hline Size percentile & $63.95 \%$ & $69.57 \%$ & $52.38 \%$ & $53.93 \%$ \\
\hline Book-to-market & 0.66 & 0.47 & 0.84 & 0.55 \\
\hline Book-to-market percentile & $42.52 \%$ & $39.18 \%$ & $47.47 \%$ & $45.43 \%$ \\
\hline \# buys/ company & 21.10 & 2 & 31.45 & 15 \\
\hline \# sells/ company & 68.89 & 6 & 59.17 & 20 \\
\hline \# of unique companies & 5493 & & 15276 & \\
\hline \multicolumn{5}{|c|}{ Panel B: Insider-Level Characteristics } \\
\hline & \multicolumn{2}{|c|}{ Partitionable Universe } & \multicolumn{2}{|c|}{ Insider Universe } \\
\hline & Average & Median & Average & Median \\
\hline \# buys/ insider & 4.79 & 0 & 2.35 & 1 \\
\hline Buy trade size (bps) & 16.62 & 1.94 & 14.93 & 1.61 \\
\hline$\%$ all buys that are routine & $64.44 \%$ & & & \\
\hline$\%$ all buys that are opportunistic & $35.56 \%$ & & & \\
\hline \# sells/ insider & 8.24 & 1 & 4.06 & 1 \\
\hline Sell trade size (bps) & 13.15 & 3.00 & 25.59 & 3.72 \\
\hline$\%$ all sells that are routine & $52.02 \%$ & & & \\
\hline$\%$ all sells that are opportunistic & $47.98 \%$ & & & \\
\hline \# companies/ insider & 2.23 & 2 & 2.29 & 2 \\
\hline$\%$ all trades that are routine & $54.81 \%$ & & & \\
\hline$\%$ all trades that are opportunistic & $45.19 \%$ & & & \\
\hline
\end{tabular}




\section{Table II: Performance of Routine and Opportunistic Trades}

This table reports pooled regressions of returns on indicators of routine and opportunistic trades in the prior month, over our 1989-2007 sample period. The dependent variable in each is future one-month returns (RET). Routine and opportunistic trades are defined as in Table I. Opportunistic Buy is a categorical variable equal to one if there were any opportunistic buys on a given firm in the prior month, and zero otherwise. Routine Buy is a categorical variable equal to one if there were any routine buys on a given firm in the prior month, and zero otherwise. Opportunistic Sell and Routine Sell are defined equivalently for insider sales. Size and BM are the natural logarithms of the firm characteristics of market equity and book-tomarket of the given firm. Past Month (Year) Returns are the return of the given firm over the prior month (year, excluding the prior month $(t-2, t-12)$ ). Month fixed effects (Month) are included where indicated. Standard errors clustered at the firm level. t-statistics are shown below the estimates, and 1\%, 5\%, and 10\% statistical significance are indicated with $* * *, * *$, and $*$, respectively.

\begin{tabular}{|c|c|c|c|c|c|c|}
\hline & (1) & (2) & (3) & $(4)$ & $(5)$ & (6) \\
\hline Opportunistic Buy & $\begin{array}{l}1.02^{* * *} \\
(5.24)\end{array}$ & $\begin{array}{l}0.90^{* * * *} \\
(4.64)\end{array}$ & & & $\begin{array}{l}0.65^{* * * *} \\
(2.60)\end{array}$ & $\begin{array}{l}0.57^{* *} \\
(2.30)\end{array}$ \\
\hline Routine Buy & $\begin{array}{l}0.30^{*} \\
(1.73)\end{array}$ & $\begin{array}{l}0.14 \\
(0.81)\end{array}$ & & & $\begin{array}{l}-0.08 \\
(-0.32)\end{array}$ & $\begin{array}{l}-0.20 \\
(-0.84)\end{array}$ \\
\hline Opportunistic Sell & & & $\begin{array}{l}-0.95 * * * \\
(-6.65)\end{array}$ & $\begin{array}{l}-0.78^{* * *} \\
(-5.67)\end{array}$ & $\begin{array}{l}-0.75^{* * *} \\
(-3.64)\end{array}$ & $\begin{array}{l}-0.67^{* * *} \\
(-3.37)\end{array}$ \\
\hline Routine Sell & & & $\begin{array}{l}-0.02 \\
(-0.13)\end{array}$ & $\begin{array}{l}0.04 \\
(0.24)\end{array}$ & $\begin{array}{l}0.16 \\
(0.77)\end{array}$ & $\begin{array}{l}0.14 \\
(0.69)\end{array}$ \\
\hline Size & $\begin{array}{l}-0.22^{* * *} \\
(-5.19)\end{array}$ & $\begin{array}{l}-0.20^{* * *} \\
(-4.55)\end{array}$ & $\begin{array}{l}-0.23^{* * *} \\
(-5.38)\end{array}$ & $\begin{array}{l}-0.20^{* * *} \\
(-4.70)\end{array}$ & $\begin{array}{l}-0.22^{* * *} \\
(-5.20)\end{array}$ & $\begin{array}{l}-0.20^{* * *} \\
(-4.56)\end{array}$ \\
\hline$B M$ & $\begin{array}{l}0.36^{* * * *} \\
(3.13)\end{array}$ & $\begin{array}{l}0.37^{* * *} \\
(3.30)\end{array}$ & $\begin{array}{l}0.37^{* * * *} \\
(3.26)\end{array}$ & $\begin{array}{l}0.38^{* * *} \\
(3.42)\end{array}$ & $\begin{array}{l}0.37^{* * * *} \\
(3.23)\end{array}$ & $\begin{array}{l}0.38^{* * *} \\
(3.40)\end{array}$ \\
\hline Past Month Returns & $\begin{array}{l}-0.03^{* * *} \\
(-4.00)\end{array}$ & $\begin{array}{l}-0.05^{* * *} \\
(-6.09)\end{array}$ & $\begin{array}{l}-0.03 * * * \\
(-3.93)\end{array}$ & $\begin{array}{l}-0.05^{* * *} \\
(-6.03)\end{array}$ & $\begin{array}{l}-0.03^{* * *} \\
(-3.90)\end{array}$ & $\begin{array}{l}-0.05^{* * *} \\
(-6.01)\end{array}$ \\
\hline Past Year Returns & $\begin{array}{l}0.005^{* * * *} \\
(3.68)\end{array}$ & $\begin{array}{l}0.01^{* * *} \\
(4.71)\end{array}$ & $\begin{array}{l}0.005^{* * * *} \\
(3.81)\end{array}$ & $\begin{array}{l}0.01^{* * *} \\
(4.80)\end{array}$ & $\begin{array}{l}0.01^{* * * *} \\
(3.82)\end{array}$ & $\begin{array}{l}0.01^{* * *} \\
(4.79)\end{array}$ \\
\hline Fixed Effect & & Month & & Month & & Month \\
\hline Number of observations & 48,460 & 48,460 & 48,460 & 48,460 & 48,460 & 48,460 \\
\hline
\end{tabular}




\section{Table III: Performance of Routine and Opportunistic Trades, Trade-Level Classification}

This table reports pooled regressions of returns on indicators of routine and opportunistic trades in the prior month, over our 1989-2007 sample period. The dependent variable in each is future one-month returns in month $t+1$ (RET). To define routine trades, we investigate insiders' trading patterns in the three preceding years. If an insider traded a stock in the same calendar month in three consecutive years, all trades he or she made subsequently in the same month are labeled as routine and trades made in a different month are labeled opportunistic. If an insider traded in three consecutive years, but no trades were made in the same month in these three years, all subsequent trades of that insider are labeled as opportunistic as well. Opportunistic Buy is a categorical variable equal to one if there were any opportunistic buys on a given firm in the prior month (month $t$ ), and zero otherwise. Routine Buy is a categorical variable equal to one if there were any routine buys on a given firm in the prior month (month $t$ ), and zero otherwise. Opportunistic Sell and Routine Sell are defined equivalently for insider sales. Size and BM are the natural logarithms of the firm characteristics of market equity and book-to-market of the given firm. Past Month (Year) Returns are the return of the given firm over the prior month (year, excluding the prior month $(t-2, t-12)$ ). Month fixed effects (Month) are included where indicated. Standard errors clustered at the firm level. $t$-statistics are shown below the estimates, and 1\%,5\%, and 10\% statistical significance are indicated with ***,**, and $*$, respectively.

\begin{tabular}{lllll}
\hline & $(1)$ & $(2)$ & $(3)$ & $(4)$ \\
\hline Opportunistic Buys & $0.77^{* * *}$ & $0.65^{* * *}$ & & \\
Routine Buys & $(4.39)$ & $(3.79)$ & & \\
& -0.21 & -0.29 & & \\
Opportunistic Sells & $(-1.14)$ & $(-1.57)$ & & \\
& & & $-0.77^{* * *}$ & $-0.63^{* * *}$ \\
Routine Sells & & & $(-4.66)$ & $(-3.84)$ \\
& & & $0.44^{* * *}$ & $0.31^{* *}$ \\
Size & & & $(3.06)$ & $(2.29)$ \\
& $-0.23^{* * *}$ & $-0.20^{* * *}$ & $-0.24^{* * *}$ & $-0.21^{* * *}$ \\
BM & $(-5.50)$ & $(-4.76)$ & $(-5.60)$ & $(-4.83)$ \\
& $0.38^{* * *}$ & $0.38^{* * *}$ & $0.39^{* * *}$ & $0.39^{* * *}$ \\
Past Month Returns & $(3.35)$ & $(3.47)$ & $(3.42)$ & $(3.52)$ \\
& $-0.03^{* * *}$ & $-0.05^{* * *}$ & $-0.03^{* * *}$ & $-0.05^{* * *}$ \\
Past Year Returns & $(-4.28)$ & $(-6.31)$ & $(-4.30)$ & $(-6.33)$ \\
& $0.00^{* * *}$ & $0.01^{* * *}$ & $0.00^{* * *}$ & $0.01^{* * *}$ \\
Fixed Effect & $(3.69)$ & $(4.72)$ & $(3.70)$ & $(4.72)$ \\
Number of observations & & Month & & Month \\
\hline
\end{tabular}




\section{Table IV: Portfolio Returns to Routine and Opportunistic Trades}

This table shows the returns to buy and sell portfolios that follow the routine and opportunistic trades in our opportunistic universe from 19892007. Opportunistic and routine trades are defined as in Table I. A firm is included in the opportunistic buy portfolio, for example, in month $(t+1)$ if any of its insiders placed an opportunistic buy on the firm in month $t$. At the end of the month ( $t+1)$, we rebalance the portfolios based on new insider trades. Below are the monthly returns to these opportunistic and routine buy and sell portfolios in percentages, shown for both equal and value weighting. Panel A shows results for equal-weighted portfolios, while Panel B shows results for value-weighted portfolios. $t$ statistics are shown in parentheses, and 1\%,5\%, and $10 \%$ statistical significance are indicated with $* * * * *$, and $*$, respectively.

\begin{tabular}{|c|c|c|c|c|c|c|c|c|}
\hline $\begin{array}{l}\text { Panel A: Equal- } \\
\text { weighted }\end{array}$ & $\begin{array}{l}\text { Opportunistic } \\
\text { Buys }\end{array}$ & $\begin{array}{l}\text { Routine } \\
\text { Buys }\end{array}$ & L/S Buys & $\begin{array}{l}\text { Opportunistic } \\
\text { Sells }\end{array}$ & $\begin{array}{l}\text { Routine } \\
\text { Sells }\end{array}$ & L/S Sells & $\begin{array}{l}\text { Opportunistic } \\
\text { (Buys-Sells) }\end{array}$ & $\begin{array}{l}\text { Routine } \\
\text { (Buys-Sells) }\end{array}$ \\
\hline Average returns & 2.33 & 1.65 & 0.68 & 0.77 & 1.41 & -0.63 & 1.55 & 0.25 \\
\hline Standard dev. & 4.95 & 4.06 & 3.03 & 5.97 & 6.01 & 2.64 & 4.91 & 4.67 \\
\hline CAPM alpha & $\begin{array}{l}1.51^{* * *} \\
(5.89)\end{array}$ & $\begin{array}{l}0.92^{* * *} \\
(4.34)\end{array}$ & $\begin{array}{l}0.59 * * * \\
(2.98)\end{array}$ & $\begin{array}{l}-0.30 \\
(-1.31)\end{array}$ & $\begin{array}{l}0.32 \\
(1.44)\end{array}$ & $\begin{array}{l}-0.61^{* * *} \\
(-3.47)\end{array}$ & $\begin{array}{l}1.81 * * * \\
(5.86)\end{array}$ & $\begin{array}{l}0.60^{* *} \\
(2.25)\end{array}$ \\
\hline Fama-French alpha & $\begin{array}{l}1.20^{* * *} \\
(5.49)\end{array}$ & $\begin{array}{l}0.64^{* * *} \\
(3.78)\end{array}$ & $\begin{array}{l}0.56^{* * *} \\
(2.74)\end{array}$ & $\begin{array}{l}-0.21 \\
(-1.34)\end{array}$ & $\begin{array}{l}0.43^{* * *} \\
(2.72)\end{array}$ & $\begin{array}{l}-0.65^{* * *} \\
(-3.60)\end{array}$ & $\begin{array}{l}1.41^{* * *} \\
(5.04)\end{array}$ & $\begin{array}{l}0.20 \\
(0.87)\end{array}$ \\
\hline Carhart alpha & $\begin{array}{l}1.45^{* * *} \\
(6.82)\end{array}$ & $\begin{array}{l}0.82^{* * *} \\
(4.92)\end{array}$ & $\begin{array}{l}0.63^{* * *} \\
(3.03)\end{array}$ & $\begin{array}{l}-0.19 \\
(-1.18)\end{array}$ & $\begin{array}{l}0.38^{* *} \\
(2.32)\end{array}$ & $\begin{array}{l}-0.57^{* * *} \\
(-3.11)\end{array}$ & $\begin{array}{l}1.64^{* * *} \\
(5.86)\end{array}$ & $\begin{array}{l}0.44^{*} \\
(1.89)\end{array}$ \\
\hline DGTW Char Adj & $\begin{array}{l}1.24^{* * *} \\
(4.99)\end{array}$ & $\begin{array}{l}0.40^{* *} \\
(2.00)\end{array}$ & $\begin{array}{l}0.83^{* * *} \\
(3.39)\end{array}$ & $\begin{array}{l}-0.27 * * \\
(-2.09)\end{array}$ & $\begin{array}{l}0.42^{* * *} \\
(2.75)\end{array}$ & $\begin{array}{l}-0.69 * * * \\
(-4.52)\end{array}$ & $\begin{array}{l}1.51^{* * *} \\
(4.98)\end{array}$ & $\begin{array}{l}-0.02 \\
(-0.06)\end{array}$ \\
\hline 5-Factor alpha & $\begin{array}{l}1.58^{* * *} \\
(7.03)\end{array}$ & $\begin{array}{l}0.87^{* * *} \\
(5.00)\end{array}$ & $\begin{array}{l}0.70 * * * \\
(3.18)\end{array}$ & $\begin{array}{l}-0.23 \\
(-1.30)\end{array}$ & $\begin{array}{l}0.45^{* * *} \\
(2.59)\end{array}$ & $\begin{array}{l}-0.67^{* * *} \\
(-3.48)\end{array}$ & $\begin{array}{l}1.80^{* * *} \\
(6.07)\end{array}$ & $\begin{array}{l}0.43^{*} \\
(1.73)\end{array}$ \\
\hline $\begin{array}{l}\text { Panel B: Value- } \\
\text { weighted }\end{array}$ & $\begin{array}{l}\text { Opportunistic } \\
\text { Buys }\end{array}$ & $\begin{array}{l}\text { Routine } \\
\text { Buys }\end{array}$ & L/S Buys & $\begin{array}{l}\text { Opportunistic } \\
\text { Sells }\end{array}$ & $\begin{array}{l}\text { Routine } \\
\text { Sells }\end{array}$ & L/S Sells & $\begin{array}{l}\text { Opportunistic } \\
\text { (Buys-Sells) }\end{array}$ & $\begin{array}{l}\text { Routine } \\
\text { (Buys-Sells) }\end{array}$ \\
\hline Average returns & 1.79 & 1.27 & 0.52 & 0.72 & 1.00 & -0.29 & 1.08 & 0.27 \\
\hline Standard dev. & 5.96 & 5.02 & 5.27 & 5.70 & 6.16 & 2.92 & 5.88 & 5.97 \\
\hline CAPM alpha & $\begin{array}{l}0.87^{* * *} \\
(2.88)\end{array}$ & $\begin{array}{l}0.45^{*} \\
(1.73)\end{array}$ & $\begin{array}{l}0.42 \\
(1.20)\end{array}$ & $\begin{array}{l}-0.34^{*} \\
(-1.73)\end{array}$ & $\begin{array}{l}-0.09 \\
(-0.39)\end{array}$ & $\begin{array}{l}-0.25 \\
(-1.29)\end{array}$ & $\begin{array}{l}1.22^{* * *} \\
(3.14)\end{array}$ & $\begin{array}{l}0.55 \\
(1.44)\end{array}$ \\
\hline Fama-French alpha & $\begin{array}{l}0.64^{* *} \\
(2.16)\end{array}$ & $\begin{array}{l}0.18 \\
(0.75)\end{array}$ & $\begin{array}{l}0.46 \\
(1.27)\end{array}$ & $\begin{array}{l}-0.08 \\
(-0.46)\end{array}$ & $\begin{array}{l}0.28 \\
(1.35)\end{array}$ & $\begin{array}{l}-0.36 \\
(-1.83)\end{array}$ & $\begin{array}{l}0.72^{* *} \\
(2.06)\end{array}$ & $\begin{array}{l}-0.09 \\
(-0.29)\end{array}$ \\
\hline Carhart alpha & $\begin{array}{l}0.52^{*} \\
(1.73)\end{array}$ & $\begin{array}{l}0.09 \\
(0.37)\end{array}$ & $\begin{array}{l}0.43 \\
(1.16)\end{array}$ & $\begin{array}{l}-0.09 \\
(-0.50)\end{array}$ & $\begin{array}{l}0.17 \\
(0.80)\end{array}$ & $\begin{array}{l}-0.26 \\
(-1.29)\end{array}$ & $\begin{array}{l}0.62^{*} \\
(1.71)\end{array}$ & $\begin{array}{l}-0.07 \\
(-0.22)\end{array}$ \\
\hline DGTW Char Adj & $\begin{array}{l}0.57^{* *} \\
(2.35)\end{array}$ & $\begin{array}{l}0.26 \\
(1.26)\end{array}$ & $\begin{array}{l}0.31 \\
(1.04)\end{array}$ & $\begin{array}{l}-0.18 \\
(-1.29)\end{array}$ & $\begin{array}{l}0.06 \\
(0.31)\end{array}$ & $\begin{array}{l}-0.24 \\
(-1.46)\end{array}$ & $\begin{array}{l}0.75^{* *} \\
(2.48)\end{array}$ & $\begin{array}{l}0.21 \\
(0.72)\end{array}$ \\
\hline 5-Factor alpha & $\begin{array}{l}0.72^{* *} \\
(2.27)\end{array}$ & $\begin{array}{l}0.09 \\
(0.34)\end{array}$ & $\begin{array}{l}0.63 \\
(1.61)\end{array}$ & $\begin{array}{l}-0.10 \\
(-0.49)\end{array}$ & $\begin{array}{l}0.29 \\
(1.32) \\
\end{array}$ & $\begin{array}{l}-0.39 * \\
(-1.84)\end{array}$ & $\begin{array}{l}0.82^{* *} \\
(2.15)\end{array}$ & $\begin{array}{l}-0.20 \\
(-0.57)\end{array}$ \\
\hline
\end{tabular}




\section{Table V: Opportunistic Trades and the Arrival of Information}

This table reports panel regressions of information events on the number of routine and opportunistic trades in a company in the prior month, over the 1989-2000 sample period for which we have news data. The dependent variables in the regressions are: in Columns 1 and 2, a proxy for firm information environment using the number of news, annual and quarterly earnings forecast revisions, recommendation changes, SEO and M\&A activities (All Firm Info), in Columns 3 and 4, solely the number of news (News). The main independent variables of interest are the Number of Opportunistic Trades and the Number of Routine Trades, defined as the $\log (1+$ number of opportunistic (routine) trades) in the previous month. Past 1 Month News is equal to the number of information events (for each respective specification of information events) observed for the given firm in the prior month, while Past 6 Month News is defined equivalently for information events of the firm in the 6 months prior to last month. The other independent variables are defined in Table II. Month fixed effects (Month) are included where indicated. All standard errors are adjusted for clustering at the firm level, and t-stats using these clustered standard errors are included in parentheses below the coefficient estimates; $1 \%, 5 \%$, and $10 \%$ statistical significance are indicated with ${ }^{* * *}, * *$, and $*$, respectively.

\begin{tabular}{lllll}
\hline \multirow{2}{*}{ Type of Information: } & $(1)$ & $(2)$ & $(3)$ & $(4)$ \\
\hline Number of Opportunistic Trades & $\begin{array}{l}\text { All Firm Info } \\
\text { (2.72) }\end{array}$ & All Firm Info & News & News \\
Number of Routine Trades & -0.00 & $0.03^{* * *}$ & $0.03^{* * *}$ & $0.03^{* * *}$ \\
& $(-0.11)$ & 0.02 & $(2.78)$ & $(3.26)$ \\
Size & $0.10^{* * *}$ & $0.03^{* * *}$ & 0.01 & 0.01 \\
& $(16.49)$ & $(8.01)$ & $\left(5.03^{* * *}\right.$ & $0.02^{* * *}$ \\
BM & $-0.04^{* * *}$ & -0.01 & $-0.03^{* * *}$ & -0.01 \\
& $(-3.16)$ & $(-1.58)$ & $(-3.51)$ & $(-1.46)$ \\
Past Month Returns & $-0.00^{*}$ & $0.00^{* * *}$ & -0.00 & $0.00^{* * *}$ \\
& $(-1.76)$ & $(2.86)$ & $(-0.78)$ & $(3.98)$ \\
Past Year Returns & 0.00 & 0.00 & 0.00 & 0.00 \\
& $(0.75)$ & $(1.15)$ & $(1.42)$ & $(1.13)$ \\
Past Month News & $0.58^{* * *}$ & $0.22^{* * *}$ & $0.73^{* * *}$ & $0.28^{* * *}$ \\
Past 6 Month News & $(38.68)$ & $(19.33)$ & $(54.36)$ & $(18.83)$ \\
Fixed Effect & & $0.46^{* * *}$ & & $0.39^{* * *}$ \\
Number of observations & & $(54.89)$ & & $(65.79)$ \\
\hline
\end{tabular}




\section{Table VI: What Insiders Predict and Who Mimics Their Trades}

This table reports: i.) panel regressions of announcement returns surrounding information events on the number of routine and opportunistic trades in a company in the month prior to the announcement (Columns 1-5), and ii.) panel regressions of changes in institutional holdings of a given stock on lagged and contemporaneous routine and opportunistic insider trades. As in Table V, the sample period is 1989-2000 for news and 1989-2007 for the remaining announcements. The dependent variables in the regressions are, for Columns 1-5 announcement returns on days (t-1,t+1) for the following events: News (described in Table V), Analysts' earnings forecasts + recommendations, Analysts' earnings forecasts, Managerial guidance forecasts, and Earnings Announcements. In Columns 6-8, the dependent variable is Change in total institutional holdings for the given stock being considered. The main independent variables of interest are: i.) the Number of Opportunistic Buys (Sells) and the Number of Routine Buys (Sells), defined as in Table V; these are the previous month insider trades for Columns 1-5, and previous two quarters' insider trades for the institutional holdings tests in Columns 6-8, and ii.) the Contemporaneous Opportunistic and month insider trades for Columns 1-5, and previous two quarters' insider trades for the institutional holdings tests in Columns 6-8, and ii.) the Contemporaneous Opportunistic and
Routine Insider Trades; these are the insider trades in the same quarter as the change in institutional holdings, so trading of insiders contemporaneous with trading of the institutions. Routine Insider Trades; these are the insider trades in the same quarter as the change in institutional holdings, so trading of insiders contemporaneous with trading of the institutions.
Size, B/M, and previous year returns (defined in Table II) are included as controls where indicated. Month fixed effects (Month) are also included where indicated. All standard errors are adjusted for clustering at the firm level, and t-stats using these clustered standard errors are included in parentheses below the coefficient estimates; $1 \%$, $5 \%$, and $10 \%$ statistical significance are indicated with ${ }^{* * *},{ }^{* *}$, and ${ }^{*}$, respectively.

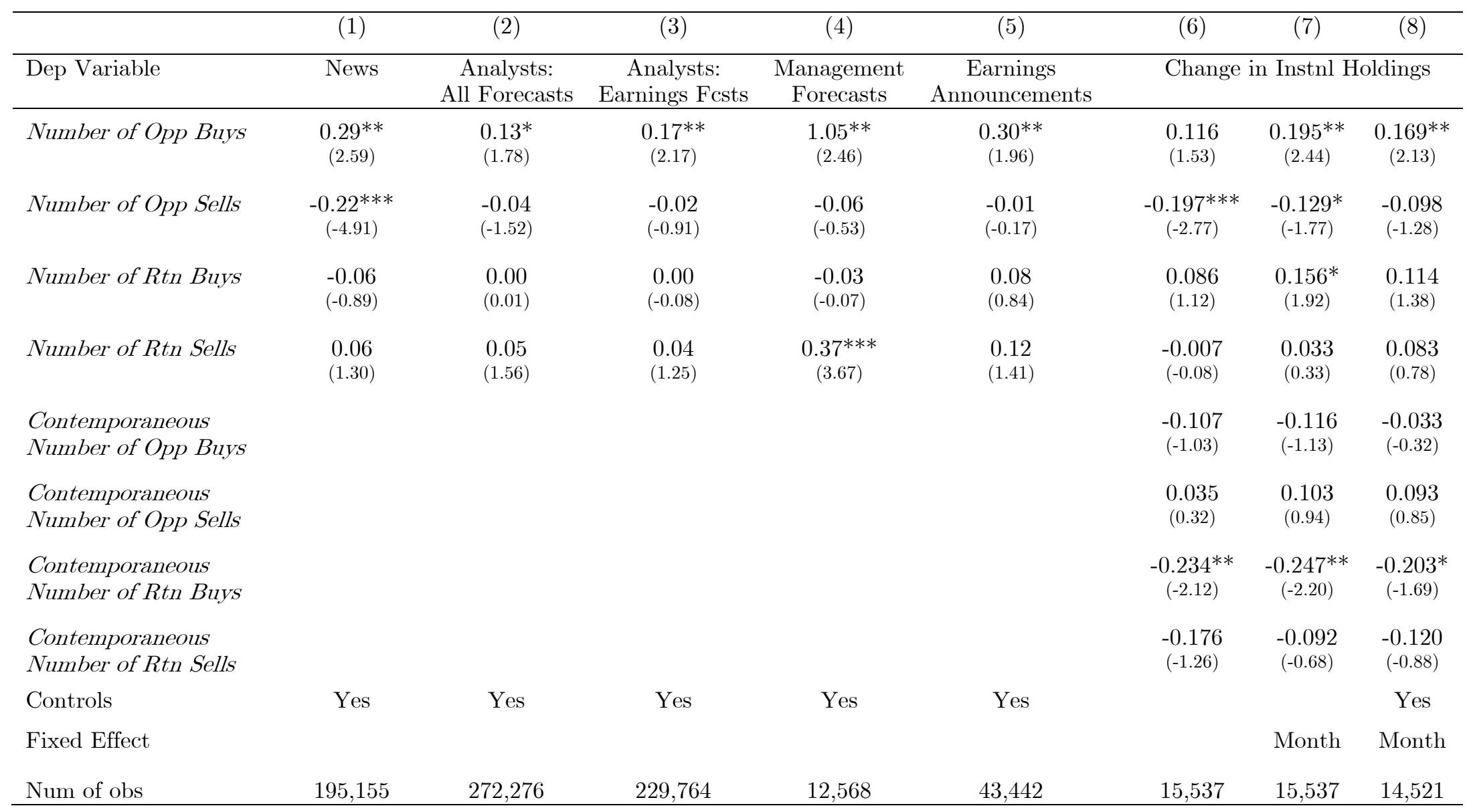




\section{Table VII: Which Opportunistic Traders Are the Most Informed?}

This table reports panel regressions of information events on the number of opportunistic trades by various insider types in a company in the prior month, over our 1989-2007 sample period. The dependent variable in the regressions is a proxy for the firm information environment using the number of news, annual and quarterly earnings forecast revisions, recommendation changes, SEO and M\&A activities. The main independent variables of interest are the Number of Opportunistic Trades, as defined in Table V, for various types of insiders. The types of insiders we consider are: Local Insiders (defined as insiders that reside in the same state as their firm's headquarters), Senior Officers of the firm (defined as CEO, CFO, or Chairman of the Board), Inside Directors, and Independent Directors of the firm. Past 1 and Past 6 Month News are defined as in Table V. The other independent variables are defined in Table II. Month fixed effects (Month) are included where indicated. All standard errors are adjusted for clustering at the firm level, and t-stats using these clustered standard errors are included in parentheses below the coefficient estimates; $1 \%, 5 \%$, and $10 \%$ statistical significance are indicated with $* * *, * *$, and $*$, respectively.

\begin{tabular}{|c|c|c|c|c|c|}
\hline & (1) & $(2)$ & $(3)$ & (4) & $(5)$ \\
\hline Opportunistic Trades by Local Insiders & $\begin{array}{l}0.03^{* * *} \\
(2.85)\end{array}$ & & & & $\begin{array}{l}0.03 * * \\
(2.22)\end{array}$ \\
\hline Opportunistic Trades by Independent Directors & & $\begin{array}{l}0.02 \\
(1.50)\end{array}$ & & & $\begin{array}{l}0.01 \\
(0.41)\end{array}$ \\
\hline Opportunistic Trades by Senior Insiders & & & $\begin{array}{l}0.01 \\
(0.96)\end{array}$ & & $\begin{array}{l}0.00 \\
(-0.11)\end{array}$ \\
\hline Opportunistic Trades by Inside Directors & & & & $\begin{array}{l}0.01 \\
(0.60)\end{array}$ & $\begin{array}{l}0.01 \\
(0.52)\end{array}$ \\
\hline Trades by Routine Insiders & $\begin{array}{l}0.01 \\
(0.93)\end{array}$ & $\begin{array}{l}-0.00 \\
(-0.04)\end{array}$ & $\begin{array}{l}0.01 \\
(0.53)\end{array}$ & $\begin{array}{l}0.00 \\
(0.39)\end{array}$ & $\begin{array}{l}0.01 \\
(0.51)\end{array}$ \\
\hline Size & $\begin{array}{l}0.03^{* * *} \\
(7.92)\end{array}$ & $\begin{array}{l}0.03^{* * * *} \\
(7.03)\end{array}$ & $\begin{array}{l}0.03^{* * *} \\
(7.93)\end{array}$ & $\begin{array}{l}0.03^{* * *} \\
(7.93)\end{array}$ & $\begin{array}{l}0.03^{* * *} \\
(7.01)\end{array}$ \\
\hline$B M$ & $\begin{array}{l}-0.01^{*} \\
(-1.71)\end{array}$ & $\begin{array}{l}-0.02^{*} \\
(-1.90)\end{array}$ & $\begin{array}{l}-0.01 * \\
(-1.79)\end{array}$ & $\begin{array}{l}-0.01^{*} \\
(-1.83)\end{array}$ & $\begin{array}{l}-0.02^{*} \\
(-1.74)\end{array}$ \\
\hline Past Month Returns & $\begin{array}{l}0.00 * * * \\
(2.93)\end{array}$ & $\begin{array}{l}0.00 * * * \\
(2.69)\end{array}$ & $\begin{array}{l}0.00 * * * \\
(3.06)\end{array}$ & $\begin{array}{l}0.00 * * * \\
(3.09)\end{array}$ & $\begin{array}{l}0.00 * * * \\
(2.50)\end{array}$ \\
\hline Past Year Returns & $\begin{array}{l}0.00 \\
(1.12)\end{array}$ & $\begin{array}{l}0.00 \\
(1.08)\end{array}$ & $\begin{array}{l}0.00 \\
(1.18)\end{array}$ & $\begin{array}{l}0.00 \\
(1.20)\end{array}$ & $\begin{array}{l}0.00 \\
(1.02)\end{array}$ \\
\hline Past Month News & $\begin{array}{l}0.22^{* * *} \\
(19.21)\end{array}$ & $\begin{array}{l}0.22^{* * *} \\
(15.63)\end{array}$ & $\begin{array}{l}0.22^{* * *} \\
(19.08)\end{array}$ & $\begin{array}{l}0.22^{* * *} \\
(19.10)\end{array}$ & $\begin{array}{l}0.22^{* * *} \\
(15.77)\end{array}$ \\
\hline Past 6 Month News & $\begin{array}{l}0.46^{* * *} \\
(54.90)\end{array}$ & $\begin{array}{l}0.49^{* * *} \\
(36.40)\end{array}$ & $\begin{array}{l}0.46^{* * *} \\
(54.77)\end{array}$ & $\begin{array}{l}0.46^{* * *} \\
(54.78)\end{array}$ & $\begin{array}{l}0.49 \text { *** } \\
(36.58)\end{array}$ \\
\hline Fixed Effect & Month & Month & Month & Month & Month \\
\hline Number of observations & 20,198 & 12,221 & 20,198 & 20,198 & 12,221 \\
\hline
\end{tabular}




\section{Table VIII: Who are the Informed Insiders?}

This table reports logit regressions of being a local opportunistic non-senior insider on a number of insiderlevel and firm-level characteristics, over our 1989-2007 sample period. The dependent variable is at the insider level, and is equal to 1 for local opportunistic non-senior (informed) insiders, and zero otherwise. Each insider, and so each independent variable, is defined when the insider is labeled as routine or opportunistic (after the insider trades three years in a row for the first time, in December of the third year with trades). The main independent variables of interest are: Number of Years Active, the number of years the given insider has been trading; Number of Trades, the number of trades the given insider has made; \# of States Operate In is $\log (1+$ the total number of states that the given firm has operations in); Herfindahl Index is a Herfindahl index of the firms operations (sales) across all states in which it operates; \% Ops in Home State is the percentage of the firm's operations located in the Headquarters state; Governance (G) Index is the Gompers, Ishii, and Metrick (2003) index of a firm's corporate governance; Poorly Governed Firm is a categorical variable equal to 1 if the firm is above the $90^{\text {th }}$ percentile in terms of poor governance score by the G Index; Number of Product Offerings is the number of products that the firm reports to sell. Past returns (Std Deviation) are defined as the return (monthly return standard deviation) in the three years prior to classification. Firm Size and BM are described in Table II. All standard errors are adjusted for clustering at the firm level, and t-stats using these clustered standard errors are included in parentheses below the coefficient estimates; $1 \%, 5 \%$, and $10 \%$ statistical significance are indicated with $* * * * *$, and $*$, respectively.

\begin{tabular}{|c|c|c|c|c|c|c|c|}
\hline & $(1)$ & $(2)$ & $(3)$ & $(4)$ & $(5)$ & $(6)$ & $(7)$ \\
\hline Number of Years Active & $\begin{array}{c}0.675^{* * *} \\
(7.47)\end{array}$ & & & & & & \\
\hline Number of Trades & $\begin{array}{c}-0.692^{* * *} \\
(-20.59)\end{array}$ & & & & & & \\
\hline Geo Dispersion: \# States Operate In & & $\begin{array}{c}-0.074^{* *} \\
(-2.34)\end{array}$ & & & & & \\
\hline Geo Dispersion: Herfindahl Index & & & $\begin{array}{c}0.436^{* * *} \\
(3.87)\end{array}$ & & & & \\
\hline Geo Dispersion: \% Ops in Home State & & & & $\begin{array}{c}0.664^{* * *} \\
(6.60)\end{array}$ & & & \\
\hline Governance $(G)$ Index & & & & & $\begin{array}{c}0.034^{* *} \\
(2.01)\end{array}$ & & \\
\hline Poorly Governed Firm & & & & & & $\begin{array}{c}0.327^{* *} \\
(2.19)\end{array}$ & \\
\hline Number of Product Offerings & & & & & & & $\begin{array}{c}0.149^{* *} \\
(2.37)\end{array}$ \\
\hline Past Firm Returns & $\begin{array}{c}0.084^{* * *} \\
(3.20)\end{array}$ & $\begin{array}{c}0.068^{* *} \\
(2.46)\end{array}$ & $\begin{array}{c}0.067^{* *} \\
(2.41)\end{array}$ & $\begin{array}{c}0.063^{* *} \\
(2.28)\end{array}$ & $\begin{array}{l}0.115 \\
(1.34)\end{array}$ & $\begin{array}{l}0.103 \\
(1.22)\end{array}$ & $\begin{array}{c}0.084^{* *} \\
(2.08)\end{array}$ \\
\hline Past Firm Std Deviation & $\begin{array}{l}-0.408 \\
(-1.44)\end{array}$ & $\begin{array}{l}-0.478 \\
(-1.57)\end{array}$ & $\begin{array}{l}-0.417 \\
(-1.37)\end{array}$ & $\begin{array}{l}-0.380 \\
(-1.22)\end{array}$ & $\begin{array}{l}0.142 \\
(0.18)\end{array}$ & $\begin{array}{l}0.064 \\
(0.08)\end{array}$ & $\begin{array}{l}-0.610 \\
(-1.36)\end{array}$ \\
\hline Size & $\begin{array}{c}0.067^{* * *} \\
(5.12)\end{array}$ & $\begin{array}{c}0.114^{* * *} \\
(7.15)\end{array}$ & $\begin{array}{c}0.120^{* * *} \\
(7.48)\end{array}$ & $\begin{array}{c}0.130^{* * *} \\
(8.10)\end{array}$ & $\begin{array}{c}0.063^{* *} \\
(2.02)\end{array}$ & $\begin{array}{c}0.067^{* *} \\
(2.14)\end{array}$ & $\begin{array}{c}0.104^{* * *} \\
(4.01)\end{array}$ \\
\hline$B M$ & $\begin{array}{l}0.006 \\
(0.20)\end{array}$ & $\begin{array}{c}0.063^{*} \\
(1.75)\end{array}$ & $\begin{array}{c}0.061^{*} \\
(1.71)\end{array}$ & $\begin{array}{c}0.071^{* *} \\
(1.97)\end{array}$ & $\begin{array}{l}-0.0001 \\
(-0.002)\end{array}$ & $\begin{array}{l}0.005 \\
(0.09)\end{array}$ & $\begin{array}{l}0.012 \\
(0.24)\end{array}$ \\
\hline Number of observations & 10,283 & 6,971 & 6,971 & 6,944 & 2,082 & 2,082 & 2,831 \\
\hline
\end{tabular}




\section{Table IX: SEC Activity and Opportunistic Trading}

This table explores the link between opportunistic trading and SEC investigations. The sample period is 1989-2007. Panel A reports regressions of the fraction of insiders trading in a given month who are opportunistic on recent SEC releases regarding litigation cases against illegal insider trading. The dependent variable is the number of opportunistic insiders trading in month $t+1$ divided by the number of all insiders trading in month $t+1$. The independent variable of interest is equal to the natural logarithm of one plus the number of SEC releases regarding litigation cases against illegal insider activity in month $t$. Panel B reports logit regressions of being investigated by the SEC. The observations are at the insider level and insider characteristics are recorded as of the end of the sample (e.g., the number of trades is the total number of trades the insider has in the sample). The independent variable of interest is an indicator variable that takes the value of one for opportunistic insiders and the number of or the fraction of opportunistic trades. The fraction of opportunistic trades is equal to one for opportunistic insiders. For routine insiders, the fraction is equal to zero if a given insider always trades in the "routine month" (the same month that she traded for the past 3 years), and can be greater than zero (but lower than one) if the insider also has some trades that are made in "non-routine" months. We also include control variables for the fraction of opportunistic insiders trading in month $t$ and month $t-1$, the CRSP value-weight market return in month $t$, the standard deviation of daily market returns in month $t$, and various windows of past cumulative market returns (month $t-3$ to $t-1$, month $t-6$ to $t-1$, and month $t-12$ to $t-1$ ). $t$-stats based on robust standard errors are included in parentheses below the coefficient estimates; $1 \%, 5 \%$, and $10 \%$ statistical significance are indicated with ***,**, and *, respectively.

\begin{tabular}{|c|c|c|c|c|c|c|c|}
\hline & (1) & $(2)$ & $(3)$ & (4) & $(5)$ & $(6)$ & (7) \\
\hline Num SEC Releases ${ }_{t}$ & $\begin{array}{l}-0.019^{* * *} \\
(-2.65)\end{array}$ & $\begin{array}{l}-0.012^{* *} \\
(-1.99)\end{array}$ & $\begin{array}{l}-0.013^{* *} \\
(-2.17)\end{array}$ & $\begin{array}{l}-0.014^{* *} \\
(-2.26)\end{array}$ & $\begin{array}{l}-0.014^{* *} \\
(-2.24)\end{array}$ & $\begin{array}{l}-0.014^{* *} \\
(-2.35)\end{array}$ & $\begin{array}{l}-0.015^{* *} \\
(-2.41)\end{array}$ \\
\hline Fraction Insiders $_{t}$ & & $\begin{array}{l}0.588^{* * *} \\
(8.77)\end{array}$ & $\begin{array}{l}0.390^{* * *} \\
(4.77)\end{array}$ & $\begin{array}{l}0.357^{* * *} \\
(4.21)\end{array}$ & $\begin{array}{l}0.352^{* * *} \\
(4.15)\end{array}$ & $\begin{array}{l}0.323^{* * *} \\
(3.84)\end{array}$ & $\begin{array}{l}0.249^{* * *} \\
(3.00)\end{array}$ \\
\hline${\text { Fraction } \text { Insiders }_{t-1}}_{1}$ & & & $\begin{array}{l}0.336^{* * *} \\
(4.59)\end{array}$ & $\begin{array}{l}0.352^{* * *} \\
(4.90)\end{array}$ & $\begin{array}{l}0.347^{* * *} \\
(4.74)\end{array}$ & $\begin{array}{l}0.320^{* * *} \\
(4.28)\end{array}$ & $\begin{array}{l}0.241^{* * *} \\
(3.07)\end{array}$ \\
\hline Market Return $_{t}$ & & & & $\begin{array}{l}0.182^{* *} \\
(2.04)\end{array}$ & $\begin{array}{l}0.158 \\
(1.39)\end{array}$ & $\begin{array}{l}0.132 \\
(1.34)\end{array}$ & $\begin{array}{l}0.089 \\
(0.95)\end{array}$ \\
\hline StdMarketRet $_{t}$ & & & & $\begin{array}{l}0.192 \\
(0.21)\end{array}$ & $\begin{array}{l}0.382 \\
(0.38)\end{array}$ & $\begin{array}{l}0.761 \\
(0.73)\end{array}$ & $\begin{array}{l}1.384 \\
(1.44)\end{array}$ \\
\hline Market Return $_{t-3, t-1}$ & & & & & $\begin{array}{l}0.033 \\
(-0.48)\end{array}$ & & \\
\hline Market Return $_{t-6, t-1}$ & & & & & & $\begin{array}{l}0.079^{*} \\
(1.67)\end{array}$ & \\
\hline Market Return $_{t-12, t-1}$ & & & & & & & $\begin{array}{l}0.116^{* * *} \\
(3.76)\end{array}$ \\
\hline $\begin{array}{l}\text { Number of } \\
\text { observations }\end{array}$ & 147 & 147 & 147 & 146 & 146 & 146 & 146 \\
\hline
\end{tabular}




\begin{tabular}{|c|c|c|c|c|}
\hline & $(1)$ & $(2)$ & $(3)$ & $(4)$ \\
\hline Opportunistic Dummy & $\begin{array}{l}1.368^{*} \\
(1.65)\end{array}$ & $\begin{array}{l}1.725^{*} \\
(1.69)\end{array}$ & $\begin{array}{l}0.057 \\
(0.07)\end{array}$ & $\begin{array}{l}0.931 \\
(1.12)\end{array}$ \\
\hline Total Num of Insider Trades & $\begin{array}{l}0.849^{* *} \\
(2.54)\end{array}$ & & & \\
\hline Num of Routine Trades & & $\begin{array}{l}0.270 \\
(0.98)\end{array}$ & & \\
\hline Num of Opportunistic Trades & & $\begin{array}{l}0.925^{* *} \\
(2.42)\end{array}$ & & \\
\hline \% Opportunistic Trades & & & $\begin{array}{l}1.653^{* * *} \\
(3.77)\end{array}$ & \\
\hline Num of Opportunistic Buys & & & & $\begin{array}{l}0.194 \\
(0.51)\end{array}$ \\
\hline Num of Opportunistic Sells & & & & $\begin{array}{l}0.945^{* * *} \\
(2.87)\end{array}$ \\
\hline Number of Observations & 11632 & 11632 & 11632 & 11632 \\
\hline
\end{tabular}




\section{Internet Appendix for "Decoding Inside Information"*}

\footnotetext{
* Citation format: Cohen, Lauren, Christopher Malloy, and Lukasz Pomorski, 20[XX], Internet Appendix to "Decoding Inside Information," Journal of Finance [], [], http://www.afajof.org/IA/[].asp. Please note: WileyBlackwell is not responsible for the content or functionality of any supporting information supplied by the authors. Any queries (other than missing material) should be directed to the authors of the article.
} 


\section{Figure A1: ABC, Inc. Example}

This figure plots the stock prices of ABC, Inc. between December 1997 and January 1998. Prices are normalized to equal 1 on the day of Mr. Johnson's (opportunistic insider) trade $(12 / 07 / 1997=1)$.

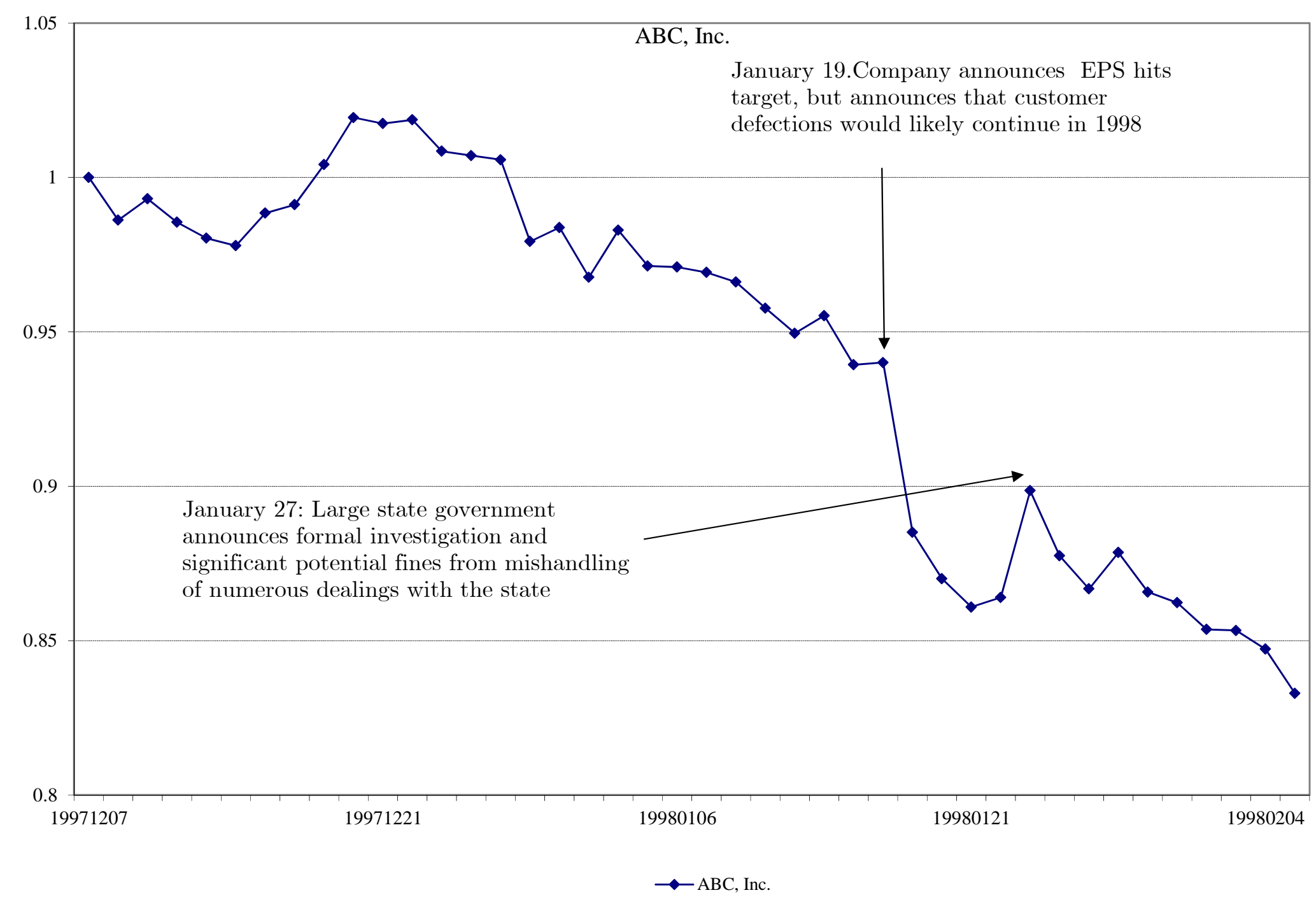




\section{Figure A2: Size distribution}

This figure plots the distribution of market capitalization of the opportunistic and routine trade sample. Every calendar month we assign stocks to size deciles using NYSE breakpoint. We plot the \% of stocks in each size bin between 1989 and 2007. D1 refers to the smallest decile of stocks, and D10 refers to the largest decile of stocks.

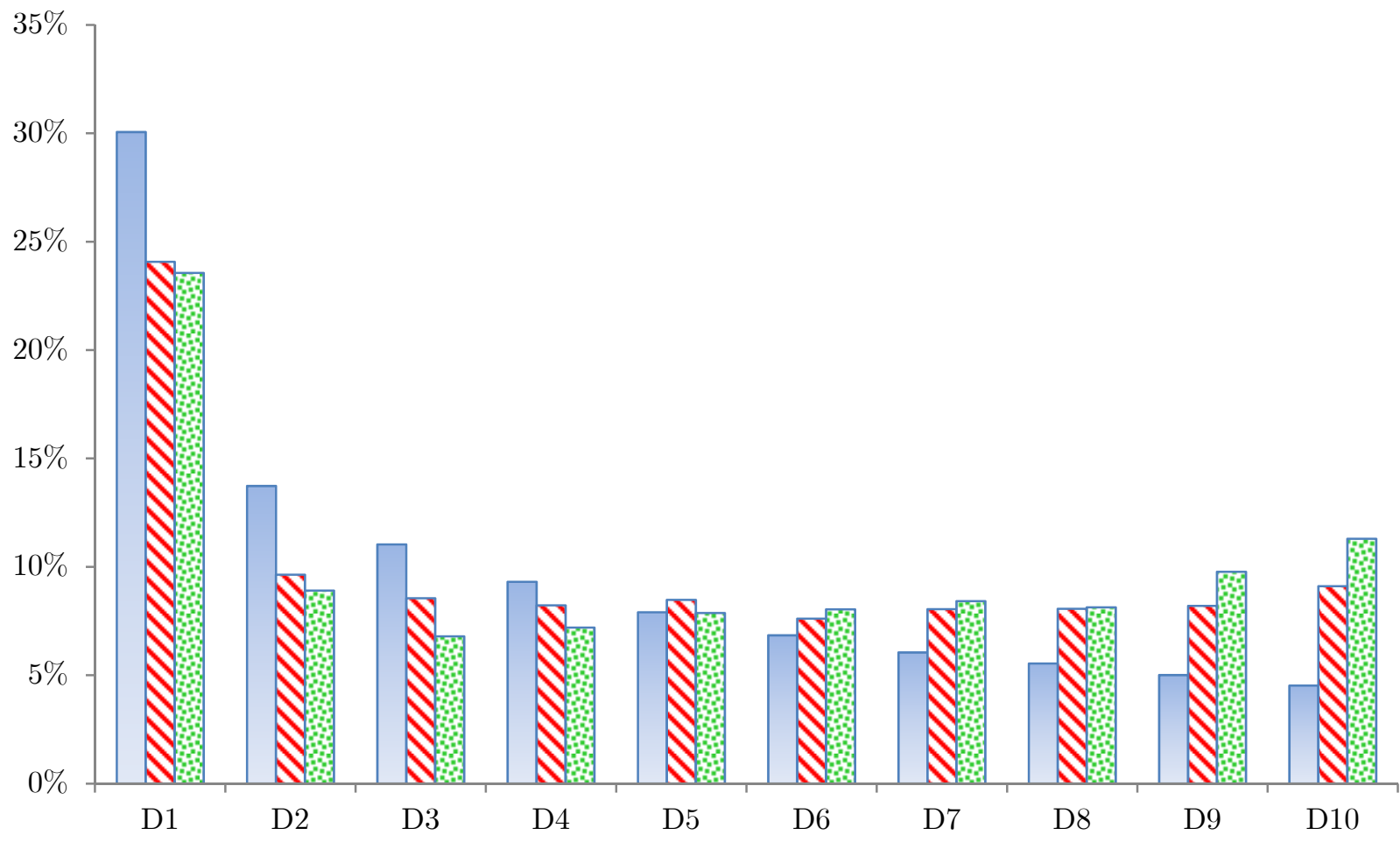

$\square$ All CRSP Stocks $\quad \square$ Stocks with opportunistic trades $\quad$ Stocks with routine trades 


\section{Table A1: Performance of Routine and Opportunistic Trades, Rolling Window Classification}

This table reports pooled regressions of returns on indicators of routine and opportunistic trades in the prior month, from 1989-2007. The dependent variable in each is future one-month returns in month $t+1$ (RET). Routine and Opportunistic traders are here defined using rolling window definitions. Specifically, at any point that an insider has a three year window of trades (trades in three consecutive years), we first classify her based on this three year window as opportunistic or routine (as described in Table I). We then roll this three year window forward a year, and reclassify the insider each year (as long as we have the three consecutive years of trading). If we do not have the three consecutive years in the following year, we retain the insider's last classification until we do. Opportunistic Buy is a categorical variable equal to one if there were any opportunistic buys on a given firm in the prior month (month $t$ ), and zero otherwise. Routine Buy is a categorical variable equal to one if there were any routine buys on a given firm in the prior month (month $t$ ), and zero otherwise. Opportunistic Sell and Routine Sell are defined equivalently for insider sales. Size and BM are the natural logarithms of the firm characteristics of market equity and book-to-market of the given firm. Past Month (Year) Returns are the return of the given firm over the prior month (year, excluding the prior month $(t-2, t-12))$. Month fixed effects (Month) are included where indicated. Standard errors clustered at the firm level. $t$-statistics are shown below the estimates, and $1 \%, 5 \%$, and $10 \%$ statistical significance are indicated with $* * * * *$, and $*$, respectively.

\begin{tabular}{lllllll}
\hline & $(1)$ & $(2)$ & $(3)$ & $(4)$ & $(5)$ & $(6)$ \\
\hline Opportunistic Buys & $1.337^{* * *}$ & $0.881^{* * *}$ & $0.715^{* * *}$ & & & \\
& $(8.69)$ & $(5.06)$ & $(4.15)$ & & & \\
Routine Buys & $0.787^{* * *}$ & 0.197 & 0.052 & & & \\
Opportunistic Sells & $(4.63)$ & $(1.07)$ & $(0.29)$ & & & \\
& & & & $-1.303^{* * *}$ & $-0.784^{* * *}$ & $-0.605^{* * *}$ \\
Routine Sells & & & $(-10.01)$ & $(-5.39)$ & $(-4.30)$ \\
Size & & & & $-0.626^{* * *}$ & -0.082 & -0.009 \\
BM & & $-0.225^{* * *}$ & $-0.199^{* * *}$ & & $-(-0.44)$ & $(-0.05)$ \\
Past Month Returns & & $(-5.23)$ & $(-4.62)$ & & $-0.226^{* * *}$ & $-0.199^{* * *}$ \\
& & $0.364^{* * *}$ & $0.376^{* * *}$ & & $0.372^{* * *}$ & $0.384^{* * *}$ \\
Past Year Returns & $(3.18)$ & $(3.37)$ & & $(3.24)$ & $(3.43)$ \\
& & $-0.031^{* * *}$ & $-0.049^{* * *}$ & & $-0.031^{* * *}$ & $-0.049^{* * *}$ \\
Fixed Effect & $(-4.02)$ & $(-6.11)$ & & $(-3.97)$ & $(-6.07)$ \\
Number of observations & 52,444 & $0.005^{* * *}$ & $0.006^{* * *}$ & & $0.005^{* * *}$ & $0.006^{* * *}$ \\
& & $(3.68)$ & $(4.72)$ & & $(3.74)$ & $(4.75)$ \\
& & & Month & & & Month \\
\hline
\end{tabular}




\section{Table A2: Portfolio Returns to Insider Trades, Young Versus Old Companies}

This table shows the returns to insider buys and insider sells in young companies (those insider trades that are made within three years of the company's first appearance in CRSP) and old companies (those insider trades that are made three or more years after the company's first appearance in CRSP). The sample period is 1989-2007. A firm is included in the buy (sell) portfolio in month ( $t+1$ ) if any of its insiders bought (sold) on the firm in month $t$. At the end of the month $(t+1)$, we rebalance the portfolios based on new insider trades. Below are the monthly returns to and alphas on these buy and sell portfolios, in percentages, shown for both equal (in Panel A) and value weighting (in Panel B). $t$ statistics are shown in parentheses, and 1\%,5\%, and $10 \%$ statistical significance are indicated with ***,**, and *, respectively.

\begin{tabular}{|c|c|c|c|c|c|c|c|c|c|}
\hline \multirow[b]{2}{*}{ Panel A: Equal weights } & \multicolumn{3}{|c|}{ Young Companies } & \multicolumn{3}{|c|}{ Old Companies } & \multicolumn{3}{|c|}{ Young Minus Old } \\
\hline & Buys & Sells & Buys-Sells & Buys & Sells & Buys-Sells & Buys & Sells & Buys-Sells \\
\hline Average returns & 1.73 & 0.56 & 1.17 & 1.95 & 0.75 & 1.20 & -0.21 & -0.18 & -0.03 \\
\hline Standard dev. & 6.55 & 8.07 & 3.45 & 5.27 & 5.34 & 2.27 & 2.94 & 4.11 & 3.02 \\
\hline CAPM alpha & $\begin{array}{l}0.91^{* * * *} \\
(3.62)\end{array}$ & $\begin{array}{l}-0.38 \\
(-1.28)\end{array}$ & $\begin{array}{l}1.29^{* * * *} \\
(6.70)\end{array}$ & $\begin{array}{l}1.20^{* * * *} \\
(6.37)\end{array}$ & $\begin{array}{l}-0.04 \\
(-0.28)\end{array}$ & $\begin{array}{l}1.24^{* * * *} \\
(9.22)\end{array}$ & $\begin{array}{l}-0.29 \\
(-1.68)\end{array}$ & $\begin{array}{l}-0.34 \\
(-1.48)\end{array}$ & $\begin{array}{l}0.05 \\
(0.28)\end{array}$ \\
\hline Fama-French alpha & $\begin{array}{l}0.95^{* * * *} \\
(4.61)\end{array}$ & $\begin{array}{l}-0.19 \\
(-1.04)\end{array}$ & $\begin{array}{l}1.14 \\
(6.82)\end{array}$ & $\begin{array}{l}1.04^{* * * *} \\
(7.34)\end{array}$ & $\begin{array}{c}-0.11 \\
(-1.51)\end{array}$ & $\begin{array}{l}1.15^{* * * *} \\
(8.92)\end{array}$ & $\begin{array}{l}-0.09 \\
(-0.64)\end{array}$ & $\begin{array}{l}-0.08 \\
(-0.45)\end{array}$ & $\begin{array}{l}-0.01 \\
(-0.09)\end{array}$ \\
\hline \multirow[t]{2}{*}{ Carhart alpha } & $\begin{array}{l}1.28^{* * * *} \\
(6.70)\end{array}$ & $\begin{array}{l}0.05 \\
(0.31)\end{array}$ & $\begin{array}{l}1.22^{* * *} \\
(7.22)\end{array}$ & $\begin{array}{l}1.31^{* * *} \\
(10.45)\end{array}$ & $\begin{array}{l}-0.10 \\
(-1.36)\end{array}$ & $\begin{array}{l}1.41^{* * *} \\
(12.74)\end{array}$ & $\begin{array}{l}-0.03 \\
(-0.22)\end{array}$ & $\begin{array}{l}0.15 \\
(0.89)\end{array}$ & $\begin{array}{c}-0.19 \\
(-1.14)\end{array}$ \\
\hline & \multicolumn{3}{|c|}{ Young Companies } & \multicolumn{3}{|c|}{ Old Companies } & \multicolumn{3}{|c|}{ Young Minus Old } \\
\hline Panel B: Value weights & Buys & Sells & Buys-Sells & Buys & Sells & Buys-Sells & Buys & Sells & Buys-Sells \\
\hline Average returns & 0.96 & 0.74 & 0.22 & 1.07 & 0.64 & 0.42 & -0.11 & 0.10 & -0.21 \\
\hline Standard dev. & 6.67 & 8.53 & 4.47 & 4.95 & 4.77 & 2.25 & 4.58 & 5.63 & 4.64 \\
\hline CAPM alpha & $\begin{array}{l}0.10 \\
(0.43)\end{array}$ & $\begin{array}{l}-0.25 \\
(-0.81)\end{array}$ & $\begin{array}{l}0.34 \\
(1.33)\end{array}$ & $\begin{array}{l}0.29 * * * \\
(2.55)\end{array}$ & $\begin{array}{l}-0.14^{* *} \\
(-2.35)\end{array}$ & $\begin{array}{l}0.43^{* * *} \\
(3.18)\end{array}$ & $\begin{array}{l}-0.20 \\
(-0.73)\end{array}$ & $\begin{array}{l}-0.11 \\
(-0.34)\end{array}$ & $\begin{array}{c}-0.09 \\
(-0.34)\end{array}$ \\
\hline Fama-French alpha & $\begin{array}{l}0.22 \\
(1.13)\end{array}$ & $\begin{array}{l}0.05 \\
(0.22)\end{array}$ & $\begin{array}{l}0.17 \\
(0.73)\end{array}$ & $\begin{array}{l}0.23^{* *} \\
(2.03)\end{array}$ & $\begin{array}{l}-0.11^{*} \\
(-1.87)\end{array}$ & $\begin{array}{l}0.33^{* *} \\
(2.56)\end{array}$ & $\begin{array}{l}0.00 \\
(-0.01)\end{array}$ & $\begin{array}{l}0.16 \\
(0.68)\end{array}$ & $\begin{array}{l}-0.16 \\
(-0.60)\end{array}$ \\
\hline Carhart alpha & $\begin{array}{l}0.21 \\
(1.05)\end{array}$ & $\begin{array}{l}-0.04 \\
(-0.19)\end{array}$ & $\begin{array}{l}0.26 \\
(1.04)\end{array}$ & $\begin{array}{l}0.35^{* * *} \\
(3.20)\end{array}$ & $\begin{array}{l}-0.15^{* * *} \\
(-2.59)\end{array}$ & $\begin{array}{l}0.50^{* * *} \\
(3.97)\end{array}$ & $\begin{array}{l}-0.14 \\
(-0.58)\end{array}$ & $\begin{array}{l}0.11 \\
(0.46)\end{array}$ & $\begin{array}{c}-0.24 \\
(-0.90)\end{array}$ \\
\hline
\end{tabular}




\section{Table A3: Portfolio Returns to Insider Trades, Young Versus Old Insiders}

This table shows the returns to buys and sells of young insiders (those insider trades that are made within three years of a given insider's first trade in the database) and of old insiders (those insider trades that are made three or more years after a given insider's first trade in the database). The sample period is 1989-2007. A firm is included in the buy (sell) portfolio in month ( $\mathrm{t}+1$ ) if any of its insiders bought (sold) on the firm in month $t$. At the end of the month $(t+1)$, we rebalance the portfolios based on new insider trades. Below are the monthly returns to and alphas on these buy and sell portfolios, in percentages, shown for both equal (in Panel A) and value weighting (in Panel B). $t$-statistics are shown in parentheses, and $1 \%, 5 \%$, and $10 \%$ statistical significance are indicated with $* * * * *$, and $*$, respectively.

\begin{tabular}{|c|c|c|c|c|c|c|c|c|c|}
\hline \multirow[b]{2}{*}{ Panel A: Equal weights } & \multicolumn{3}{|c|}{ Young Insiders } & \multicolumn{3}{|c|}{ Old Insiders } & \multicolumn{3}{|c|}{ Young Minus Old } \\
\hline & Buys & Sells & Buys-Sells & Buys & Sells & Buys-Sells & Buys & Sells & Buys-Sells \\
\hline Average returns & 1.95 & 0.65 & 1.30 & 1.98 & 0.83 & 1.14 & 0.00 & -0.18 & 0.17 \\
\hline Standard dev. & 5.70 & 6.18 & 2.59 & 5.53 & 5.44 & 3.22 & 2.15 & 1.84 & 2.08 \\
\hline CAPM alpha & $\begin{array}{l}1.17^{* * * *} \\
(5.67)\end{array}$ & $\begin{array}{l}-0.20 \\
(-1.04)\end{array}$ & $\begin{array}{l}1.36^{* * * *} \\
(9.11)\end{array}$ & $\begin{array}{l}1.26^{* * *} \\
(5.24)\end{array}$ & $\begin{array}{l}0.09 \\
(0.51)\end{array}$ & $\begin{array}{l}1.19^{* * * *} \\
(5.80)\end{array}$ & $\begin{array}{l}-0.02 \\
(-0.15)\end{array}$ & $\begin{array}{l}-0.22^{*} \\
(-1.89)\end{array}$ & $\begin{array}{l}0.18 \\
(1.33)\end{array}$ \\
\hline Fama-French alpha & $\begin{array}{l}1.08^{* * *} \\
(6.78)\end{array}$ & $\begin{array}{l}-0.15 \\
(-1.73)\end{array}$ & $\begin{array}{l}1.23^{* * *} \\
(9.17)\end{array}$ & $\begin{array}{l}1.08^{* * *} \\
(5.37)\end{array}$ & $\begin{array}{l}0.02 \\
(0.22)\end{array}$ & $\begin{array}{l}1.08^{* * * *} \\
(5.48)\end{array}$ & $\begin{array}{l}0.03 \\
(0.24)\end{array}$ & $\begin{array}{l}-0.15 \\
(-1.43)\end{array}$ & $\begin{array}{l}0.16 \\
(1.19)\end{array}$ \\
\hline \multirow[t]{2}{*}{ Carhart alpha } & $\begin{array}{l}1.38^{* * * *} \\
(9.93)\end{array}$ & $\begin{array}{l}-0.10 \\
(-1.14)\end{array}$ & $\begin{array}{l}1.48^{* * *} \\
(12.64)\end{array}$ & $\begin{array}{l}1.46^{* * *} \\
(8.07)\end{array}$ & $\begin{array}{l}0.02 \\
(0.17)\end{array}$ & $\begin{array}{l}1.47^{* * *} \\
(8.36)\end{array}$ & $\begin{array}{l}0.03 \\
(0.20)\end{array}$ & $\begin{array}{l}-0.08 \\
(-0.79)\end{array}$ & $\begin{array}{l}0.10 \\
(0.72)\end{array}$ \\
\hline & \multicolumn{3}{|c|}{ Young Insiders } & \multicolumn{3}{|c|}{ Old Insiders } & \multicolumn{3}{|c|}{ Young Minus Old } \\
\hline Panel B: Value weights & Buys & Sells & Buys-Sells & Buys & Sells & Buys-Sells & Buys & Sells & Buys-Sells \\
\hline Average returns & 1.09 & 0.58 & 0.52 & 1.09 & 0.70 & 0.32 & -0.02 & -0.18 & 0.21 \\
\hline Standard dev. & 5.21 & 5.04 & 2.79 & 4.94 & 4.72 & 3.15 & 2.87 & 1.43 & 3.09 \\
\hline CAPM alpha & $\begin{array}{l}0.30^{* *} \\
(2.38)\end{array}$ & $\begin{array}{l}-0.22^{* *} \\
(-2.45)\end{array}$ & $\begin{array}{l}0.52^{* * *} \\
(3.09)\end{array}$ & $\begin{array}{l}0.37^{* *} \\
(2.20)\end{array}$ & $\begin{array}{l}-0.02 \\
(-0.28)\end{array}$ & $\begin{array}{l}0.35 \\
(1.73)\end{array}$ & $\begin{array}{l}-0.04 \\
(-0.25)\end{array}$ & $\begin{array}{l}-0.17 \\
(-1.87)\end{array}$ & $\begin{array}{l}0.18 \\
(0.89)\end{array}$ \\
\hline Fama-French alpha & $\begin{array}{l}0.26^{* *} \\
(2.07)\end{array}$ & $\begin{array}{l}-0.13 \\
(-1.63)\end{array}$ & $\begin{array}{l}0.39^{* *} \\
(2.43)\end{array}$ & $\begin{array}{l}0.31^{*} \\
(1.86)\end{array}$ & $\begin{array}{l}0.03 \\
(0.38)\end{array}$ & $\begin{array}{l}0.23 \\
(1.22)\end{array}$ & $\begin{array}{l}-0.02 \\
(-0.13)\end{array}$ & $\begin{array}{l}-0.15 \\
(-1.61)\end{array}$ & $\begin{array}{l}0.17 \\
(0.84)\end{array}$ \\
\hline Carhart alpha & $\begin{array}{l}0.40^{* * *} \\
(3.25)\end{array}$ & $\begin{array}{l}-0.23^{* * *} \\
(-3.07)\end{array}$ & $\begin{array}{l}0.64^{* * *} \\
(4.22)\end{array}$ & $\begin{array}{l}0.49 * * * \\
(3.03)\end{array}$ & $\begin{array}{l}-0.04 \\
(-0.49)\end{array}$ & $\begin{array}{l}0.49 * * * \\
(2.64)\end{array}$ & $\begin{array}{l}-0.03 \\
(-0.18)\end{array}$ & $\begin{array}{l}-0.19 \\
(-2.11)\end{array}$ & $\begin{array}{l}0.22 \\
(1.05)\end{array}$ \\
\hline
\end{tabular}


Table A4: Portfolio Returns to Non-Classified Trades

This table shows the returns to the naïve insider mimicking portfolio (insider purchases minus insider sales) for the sample we employ in this paper, as well as for the sample of non-classified trades that do not enter our sample. The sample period is 1989-2007. A firm is included in the buy (sell) portfolio in month ( $t+1$ ) if any of its insiders bought (sold) on the firm in month $t$. At the end of the month ( $t+1$ ), we rebalance the portfolios based on new insider trades. Below are the value-weighted monthly returns to and alphas on these buy and sell portfolios, in percentages. $t$-statistics are shown in parentheses, and 1\%, $5 \%$, and $10 \%$ statistical significance are indicated with $* * *, * *$, and $*$, respectively.

\begin{tabular}{|c|c|c|c|}
\hline & \multicolumn{3}{|c|}{$\begin{array}{l}\text { Naïve Insider Mimicking Portfolio } \\
\text { (Buys-Sells) }\end{array}$} \\
\hline & Our universe & Non-classified & Our Minus Non-classified \\
\hline Average Value-Weighted Return & 0.61 & 0.37 & 0.24 \\
\hline \multirow[t]{2}{*}{ Standard Deviation } & 4.89 & 2.32 & 4.78 \\
\hline & $(1.90)$ & $(2.43)$ & $(0.77)$ \\
\hline \multirow[t]{2}{*}{ CAPM alpha } & 0.82 & 0.39 & 0.43 \\
\hline & $(2.61)$ & $(2.57)$ & $(1.42)$ \\
\hline \multirow[t]{2}{*}{ Fama-French alpha } & 0.31 & 0.24 & 0.07 \\
\hline & $(1.19)$ & $(1.58)$ & $(0.26)$ \\
\hline \multirow[t]{2}{*}{ Carhart alpha } & 0.28 & 0.47 & -0.20 \\
\hline & $(1.09)$ & $(2.44)$ & $(-0.60)$ \\
\hline
\end{tabular}




\section{Table A5: Including Non-Classified Trades in Baseline Regressions}

This table reports pooled regressions of returns on indicators of routine and opportunistic trades in the prior month, over our 1989-2007 sample period. The dependent variable in each is future one-month returns. Opportunistic Buy, Routine Buy, Opportunistic Sell, and Routine Sell are categorical variables defined as in Table II. In Columns 3 and 4, non-classified trades are categorized as opportunistic trades; in Columns 5 and 6 , non-classified trades are categorized as routine trades. Controls for the natural logarithm of market equity and book-to-market of the given firm, past returns of the given firm over the prior month and prior year (excluding the prior month $(t-2, t-12)$ ), and month fixed effects, are included in all specifications. Standard errors clustered at the firm level. t-statistics are shown below the estimates, and $1 \%$, $5 \%$, and $10 \%$ statistical significance are indicated with $* * *, * *$, and $*$, respectively.

\begin{tabular}{|c|c|c|c|c|c|c|}
\hline & (1) & $(2)$ & $(3)$ & $(4)$ & $(5)$ & $(6)$ \\
\hline $\begin{array}{l}\text { How Non-classified trades are } \\
\text { included: }\end{array}$ & \multicolumn{2}{|c|}{$\begin{array}{l}\text { Non-classified trades not } \\
\text { included }\end{array}$} & \multicolumn{2}{|c|}{$\begin{array}{l}\text { Non-classified trades included as } \\
\text { Opportunistic }\end{array}$} & \multicolumn{2}{|c|}{$\begin{array}{l}\text { Non-classified trades included as } \\
\text { Routine }\end{array}$} \\
\hline Opportunistic Buy & $\begin{array}{r}0.90^{* *} \\
(4.64)\end{array}$ & & $\begin{array}{c}0.85^{* * *} \\
(5.50)\end{array}$ & & $\begin{array}{r}0.89^{* * *} \\
(4.63)\end{array}$ & \\
\hline Routine Buy & $\begin{array}{c}0.14 \\
(0.81)\end{array}$ & & $\begin{array}{c}0.03 \\
(0.17)\end{array}$ & & $\begin{array}{l}0.36^{* *} \\
(2.43)\end{array}$ & \\
\hline Opportunistic Sell & & $\begin{array}{c}-0.78^{* * *} \\
(-5.67)\end{array}$ & & $\begin{array}{c}-0.72^{* * *} \\
(-5.10)\end{array}$ & & $\begin{array}{c}-0.81^{* * *} \\
(-6.48)\end{array}$ \\
\hline Routine Sell & & $\begin{array}{c}0.04 \\
(0.24)\end{array}$ & & $\begin{array}{l}0.26^{*} \\
(1.90)\end{array}$ & & $\begin{array}{l}-0.19 \\
(-1.44)\end{array}$ \\
\hline Controls & Yes & Yes & Yes & Yes & Yes & Yes \\
\hline Month FE & Yes & Yes & Yes & Yes & Yes & Yes \\
\hline R-squared & 0.108 & 0.108 & 0.108 & 0.108 & 0.108 & 0.108 \\
\hline
\end{tabular}




\section{Table A6: Correlation Between Routine and Opportunistic Trades, 1989-2007}

Pearson correlation coefficients are calculated over all months and over all available stocks for the following variables. \# Opportunistic Buys is the number of opportunistic buys for the given firm and month, and \# Routine Buys is the number of routine buys in the given firm in the given month. These variables are defined analogously for sells. $\log ($ Size) is the log of market capitalization as of the end of the previous calendar month. $\log (\mathrm{B} / \mathrm{M})$ the $\log$ of the book-market ratio, which is the market value of equity divided by Compustat book value of equity. The timing of $\mathrm{B} / \mathrm{M}$ follows Fama and French (1993) and is as of the previous December year-end. RET is the return in the prior 12 months before the month of trading for the given firm and month.

\begin{tabular}{|c|c|c|c|c|c|c|c|}
\hline & $\begin{array}{r}\text { \# Opportunistic } \\
\text { Buys }\end{array}$ & $\begin{array}{r}\text { \# Routine } \\
\text { Buys }\end{array}$ & $\begin{array}{r}\text { \# Opportunistic } \\
\text { Sells }\end{array}$ & $\begin{array}{r}\text { \# Routine } \\
\text { Sells }\end{array}$ & $\log (\operatorname{Size})$ & $\log (B / M)$ & $R E T$ \\
\hline \# Opportunistic Buys & 1 & -0.001 & -0.029 & -0.016 & -0.079 & 0.066 & -0.024 \\
\hline \# Routine Buys & & 1 & -0.017 & -0.008 & -0.039 & 0.011 & 0.002 \\
\hline \# Opportunistic Sells & & & 1 & 0.001 & 0.101 & -0.059 & 0.015 \\
\hline \# Routine Sells & & & & 1 & 0.111 & -0.091 & 0.005 \\
\hline $\log ($ Size $)$ & & & & & 1 & -0.436 & 0.122 \\
\hline $\log (B / M)$ & & & & & & 1 & -0.118 \\
\hline$R E T$ & & & & & & & 1 \\
\hline
\end{tabular}




\section{Table A7: Performance of Routine and Opportunistic Trades, Waiting Until 11th Day of Following Month}

This table reports pooled regressions of returns on indicators of routine and opportunistic trades in the prior month, from 1989-2007. The dependent variable in each is future one-month returns, computed from the $11^{\text {th }}$ day of the month subsequent to when insiders trade (i.e., month $t+1$ ) to the $10^{\text {th }}$ day of the following month (i.e., month $t+2$ ). Routine and opportunistic trades are defined as in Table I. Opportunistic Buy is a categorical variable equal to one if there were any opportunistic buys on a given firm in the prior month (month $t$ ), and zero otherwise. Routine Buy is a categorical variable equal to one if there were any routine buys on a given firm in the prior month (month $t$ ), and zero otherwise. Opportunistic Sell and Routine Sell are defined equivalently for insider sales. Size and BM are the natural logarithms of the firm characteristics of market equity and book-to-market of the given firm. Past Month (Year) Returns are the return of the given firm over the prior month (year, excluding the prior month $(t-2, t-12))$. Month fixed effects (Month) are included where indicated. Standard errors clustered at the firm level. $t$-statistics are shown below the estimates, and 1\%, $5 \%$, and $10 \%$ statistical significance are indicated with $* * *, * *$, and $*$, respectively.

\begin{tabular}{|c|c|c|c|c|c|c|}
\hline & (1) & $(2)$ & $(3)$ & $(4)$ & $(5)$ & $(6)$ \\
\hline Opportunistic Buy & $\begin{array}{l}1.43^{* * *} \\
(7.86)\end{array}$ & $\begin{array}{l}1.05^{* * *} \\
(5.39)\end{array}$ & $\begin{array}{l}1.00 \text { *** } \\
(5.26)\end{array}$ & & & \\
\hline Routine Buy & $\begin{array}{l}0.88^{* * *} \\
(6.07)\end{array}$ & $\begin{array}{l}0.35^{* *} \\
(2.20)\end{array}$ & $\begin{array}{l}0.20 \\
(1.26)\end{array}$ & & & \\
\hline Opportunistic Sell & & & & $\begin{array}{l}-1.46^{* * *} \\
(-11.41)\end{array}$ & $\begin{array}{l}-1.04^{* * *} \\
(-7.45)\end{array}$ & $\begin{array}{l}-0.90^{* * *} \\
(-6.58)\end{array}$ \\
\hline Routine Sell & & & & $\begin{array}{l}-0.59^{* * *} \\
(-4.24)\end{array}$ & $\begin{array}{l}-0.11 \\
(-0.72)\end{array}$ & $\begin{array}{l}-0.12 \\
(-0.84)\end{array}$ \\
\hline Size & & $\begin{array}{l}-0.16^{* * *} \\
(-4.19)\end{array}$ & $\begin{array}{l}-0.13^{* * *} \\
(-3.34)\end{array}$ & & $\begin{array}{l}-0.17^{* * *} \\
(-4.24)\end{array}$ & $\begin{array}{l}-0.13^{\text {*** }} \\
(-3.38)\end{array}$ \\
\hline$B M$ & & $\begin{array}{l}0.44^{* * *} \\
(3.93)\end{array}$ & $\begin{array}{l}0.40^{* * * *} \\
(3.70)\end{array}$ & & $\begin{array}{l}0.44^{* * * *} \\
(3.97)\end{array}$ & $\begin{array}{l}0.40^{* * *} \\
(3.70)\end{array}$ \\
\hline Past Month Returns & & $\begin{array}{l}0.01 \\
(0.82)\end{array}$ & $\begin{array}{l}-0.01 \\
(-1.59)\end{array}$ & & $\begin{array}{l}0.01 \\
(0.89)\end{array}$ & $\begin{array}{l}-0.01 \\
(-1.51)\end{array}$ \\
\hline Past Year Returns & & $\begin{array}{l}0.00 \\
(0.64)\end{array}$ & $\begin{array}{l}0.00^{* *} \\
(2.06)\end{array}$ & & $\begin{array}{l}0.00 \\
(0.76)\end{array}$ & $\begin{array}{l}0.00^{* *} \\
(2.15)\end{array}$ \\
\hline Fixed Effect & & & Month & & & Month \\
\hline Number of observations & 52,444 & 48,460 & 48,460 & 52,444 & 48,460 & 48,460 \\
\hline
\end{tabular}


Table A8: Trade-Weighted Portfolio Returns to Routine and Opportunistic Trades

This table shows the returns to buy and sell trade-weighted portfolios that follow the routine and opportunistic trades in our opportunistic universe from 1989-2007. Opportunistic and routine trades are defined as in Table I. A firm is included in the opportunistic buy portfolio, for example, in month $(t+1)$ if any of its insiders placed an opportunistic buy on the firm in month $t$. At the end of the month ( +1$)$, we rebalance the portfolios based on new insider trades. Below are the monthly returns to these opportunistic and routine buy and sell portfolios in percentages, shown for both equal and value weighting. Panels A and B shows results for dollar trade-weighted, using self-reported transaction prices and CRSP end of day transaction prices, while Panel $\mathrm{C}$ shows results using portfolio weights by respective \% shares outstanding. $t$-statistics are shown in parentheses, and 1\%,5\%, and 10\% statistical significance are indicated with ***,**, and *, respectively.

\begin{tabular}{|c|c|c|c|c|c|c|c|c|}
\hline & $\begin{array}{l}\text { Opportunistic } \\
\text { Buys }\end{array}$ & $\begin{array}{l}\text { Routine } \\
\text { Buys }\end{array}$ & $\begin{array}{l}\text { L/S } \\
\text { Buys } \\
\end{array}$ & $\begin{array}{l}\text { Opportunistic } \\
\text { Sells }\end{array}$ & $\begin{array}{l}\text { Routine } \\
\text { Sells }\end{array}$ & $\begin{array}{l}\mathrm{L} / \mathrm{S} \\
\text { Sells } \\
\end{array}$ & $\begin{array}{l}\text { Opportunistic } \\
\text { (Buys-Sells) }\end{array}$ & $\begin{array}{l}\text { Routine } \\
\text { (Buys-Sells) }\end{array}$ \\
\hline Average returns & 2.18 & 1.50 & 0.69 & 0.93 & 1.50 & -0.56 & 1.25 & -0.0002 \\
\hline Standard dev. & 5.75 & 5.29 & 5.60 & 7.75 & 6.48 & 5.87 & 7.55 & 6.68 \\
\hline CAPM alpha & $\begin{array}{l}1.32^{* * *} \\
(4.28)\end{array}$ & $\begin{array}{l}0.75^{* *} \\
(2.42)\end{array}$ & $\begin{array}{l}0.58 \\
(1.54)\end{array}$ & $\begin{array}{l}-0.15 \\
(-0.37)\end{array}$ & $\begin{array}{l}0.43 \\
(1.50)\end{array}$ & $\begin{array}{l}-0.58 \\
(-1.47)\end{array}$ & $\begin{array}{c}1.47^{* * *} \\
(2.97)\end{array}$ & $\begin{array}{c}0.32 \\
(0.74)\end{array}$ \\
\hline Fama-French alpha & $\begin{array}{l}1.05^{* * *} \\
(3.66)\end{array}$ & $\begin{array}{l}0.46 \\
(1.59)\end{array}$ & $\begin{array}{l}0.59 \\
(1.54)\end{array}$ & $\begin{array}{l}-0.01 \\
(-0.03)\end{array}$ & $\begin{array}{l}0.67^{* *} \\
(2.52)\end{array}$ & $\begin{array}{l}-0.68^{*} \\
(-1.69)\end{array}$ & $\begin{array}{c}1.06^{* *} \\
(2.18)\end{array}$ & $\begin{array}{l}-0.20 \\
(-0.51)\end{array}$ \\
\hline Carhart alpha & $\begin{array}{l}1.18^{* * * *} \\
(4.02) \\
\end{array}$ & $\begin{array}{l}0.64^{* *} \\
(2.16) \\
\end{array}$ & $\begin{array}{l}0.54 \\
(1.38) \\
\end{array}$ & $\begin{array}{l}0.02 \\
(0.06) \\
\end{array}$ & $\begin{array}{l}0.47^{*} \\
(1.75) \\
\end{array}$ & $\begin{array}{l}-0.44 \\
(-1.09) \\
\end{array}$ & $\begin{array}{c}1.15^{* *} \\
(2.30) \\
\end{array}$ & $\begin{array}{l}0.17 \\
(0.43) \\
\end{array}$ \\
\hline \multicolumn{9}{|c|}{ Panel B: Dollar trade-size weighted (using CRSP end of transaction-day price for transaction price) } \\
\hline Average returns & 2.09 & 1.45 & 0.64 & 0.90 & 1.45 & -0.56 & 1.20 & -0.001 \\
\hline Standard dev. & 5.73 & 5.26 & 5.59 & 7.66 & 6.40 & 5.94 & 7.38 & 6.60 \\
\hline CAPM alpha & $\begin{array}{l}1.23^{* * *} \\
(4.02)\end{array}$ & $\begin{array}{l}0.71^{* *} \\
(2.31)\end{array}$ & $\begin{array}{l}0.52 \\
(1.40)\end{array}$ & $\begin{array}{l}-0.17 \\
(-0.44)\end{array}$ & $\begin{array}{l}0.40 \\
(1.41)\end{array}$ & $\begin{array}{l}-0.57 \\
(-1.44)\end{array}$ & $\begin{array}{c}1.40^{* * *} \\
(2.89)\end{array}$ & $\begin{array}{l}0.31 \\
(0.75)\end{array}$ \\
\hline Fama-French alpha & $\begin{array}{l}0.94^{* * *} \\
(3.37)\end{array}$ & $\begin{array}{l}0.41 \\
(1.43)\end{array}$ & $\begin{array}{l}0.53 \\
(1.40)\end{array}$ & $\begin{array}{l}-0.06 \\
(-0.16)\end{array}$ & $\begin{array}{l}0.61^{* *} \\
(2.30)\end{array}$ & $\begin{array}{l}-0.67^{* *} \\
(-1.65)\end{array}$ & $\begin{array}{c}1.01^{* *} \\
(2.10)\end{array}$ & $\begin{array}{l}-0.19 \\
(-0.49)\end{array}$ \\
\hline Carhart alpha & $\begin{array}{l}1.09 * * * \\
(3.83) \\
\end{array}$ & $\begin{array}{l}0.58 * * \\
(1.98) \\
\end{array}$ & $\begin{array}{l}0.51 \\
(1.31) \\
\end{array}$ & $\begin{array}{l}0.01 \\
(0.03) \\
\end{array}$ & $\begin{array}{l}0.42 \\
(1.58) \\
\end{array}$ & $\begin{array}{c}-0.41 \\
(-0.99) \\
\end{array}$ & $\begin{array}{c}1.08^{* *} \\
(2.19) \\
\end{array}$ & $\begin{array}{r}0.16 \\
(0.41) \\
\end{array}$ \\
\hline \multicolumn{9}{|c|}{ Panel C: Percentage shares outstanding weighted } \\
\hline Average returns & 2.09 & 2.02 & 0.07 & 0.90 & 1.75 & -0.85 & 1.20 & 0.27 \\
\hline Standard dev. & 5.63 & 5.72 & 5.60 & 8.00 & 6.71 & 5.79 & 7.86 & 6.45 \\
\hline CAPM alpha & $\begin{array}{l}1.29^{* * *} \\
(4.06)\end{array}$ & $\begin{array}{l}1.24^{* * *} \\
(3.74)\end{array}$ & $\begin{array}{l}0.06 \\
(0.15)\end{array}$ & $\begin{array}{l}-0.24 \\
(-0.60)\end{array}$ & $\begin{array}{l}0.70^{* *} \\
(2.21)\end{array}$ & $\begin{array}{l}-0.94^{* *} \\
(-2.44)\end{array}$ & $\begin{array}{c}1.53^{* * *} \\
(3.04)\end{array}$ & $\begin{array}{c}0.53 \\
(1.28)\end{array}$ \\
\hline Fama-French alpha & $\begin{array}{l}1.02^{* * * *} \\
(3.41)\end{array}$ & $\begin{array}{l}0.96^{* * * *} \\
(3.19)\end{array}$ & $\begin{array}{l}0.06 \\
(0.16)\end{array}$ & $\begin{array}{l}-0.10 \\
(-0.28)\end{array}$ & $\begin{array}{l}0.87^{* * *} \\
(3.06)\end{array}$ & $\begin{array}{l}-0.96^{* *} \\
(-2.45)\end{array}$ & $\begin{array}{c}1.12^{* *} \\
(2.30)\end{array}$ & $\begin{array}{l}0.09 \\
(0.23)\end{array}$ \\
\hline Carhart alpha & $\begin{array}{l}1.15^{* * *} \\
(3.76) \\
\end{array}$ & $\begin{array}{l}1.24^{* * *} \\
(4.13)\end{array}$ & $\begin{array}{l}-0.09 \\
(-0.22) \\
\end{array}$ & $\begin{array}{l}0.07 \\
(0.18) \\
\end{array}$ & $\begin{array}{l}0.75^{* *} \\
(2.59) \\
\end{array}$ & $\begin{array}{l}-0.68^{*} \\
(-1.72) \\
\end{array}$ & $\begin{array}{c}1.09^{* *} \\
(2.16) \\
\end{array}$ & $\begin{array}{c}0.49 \\
(1.23) \\
\end{array}$ \\
\hline
\end{tabular}




\section{Table A9: Impact of the Number of Routine and Opportunistic Trades}

This table reports panel regressions of returns on continuous measures of the number of routine and opportunistic trades in the prior month, from 1989-2007. The dependent variable in each is future one-month returns (RET). Routine and opportunistic trades are defined as in Table I. Number of Opportunistic Buys is equal to the natural logarithm of one plus the number of opportunistic buys in the given firm for the prior month (so is equal to zero if there were zero trades). Number of Routine Buys is equal to the natural logarithm of one plus the number of routine buys in the given firm for the prior month (so is equal to zero if there were zero trades). Number of Opportunistic Sells and Number of Routine Sells are defined equivalently for insider sales. Size and BM are the natural logarithms of the firm characteristics of market equity and book-tomarket of the given firm. Past Returns are the return of the given firm over the prior sixth month period. Month fixed effects (Month) are included where indicated. All standard errors are adjusted for clustering at the firm level, and t-stats using these clustered standard errors are included in parentheses below the coefficient estimates; $1 \%, 5 \%$, and $10 \%$ statistical significance are indicated with $* * * * *$, and $*$, respectively.

\begin{tabular}{|c|c|c|c|c|c|c|c|c|c|}
\hline & $(1)$ & $(2)$ & (3) & $(4)$ & $(5)$ & $(6)$ & $(7)$ & $(8)$ & (9) \\
\hline Number of Opportunistic Buys & $\begin{array}{l}0.95^{* * *} \\
(6.77)\end{array}$ & $\begin{array}{l}0.74^{* * *} \\
(4.97)\end{array}$ & $\begin{array}{l}0.66^{* * *} \\
(4.56)\end{array}$ & & & & $\begin{array}{l}0.67^{* * *} \\
(4.52)\end{array}$ & $\begin{array}{l}0.61^{* * *} \\
(3.97)\end{array}$ & $\begin{array}{l}0.59 * * * \\
(3.93)\end{array}$ \\
\hline Number of Routine Buys & $\begin{array}{l}0.39 * * * \\
(4.09)\end{array}$ & $\begin{array}{l}0.10 \\
(0.92)\end{array}$ & $\begin{array}{l}0.01 \\
(0.12)\end{array}$ & & & & $\begin{array}{l}0.14 \\
(1.37)\end{array}$ & $\begin{array}{l}-0.02 \\
(-0.16)\end{array}$ & $\begin{array}{l}-0.05 \\
(-0.43)\end{array}$ \\
\hline Number of Opportunistic Sells & & & & $\begin{array}{l}-0.63^{* * *} \\
(-10.29)\end{array}$ & $\begin{array}{l}-0.43^{* * *} \\
(-6.75)\end{array}$ & $\begin{array}{l}-0.31^{* * *} \\
(-4.97)\end{array}$ & $\begin{array}{l}-0.49 * * * \\
(-7.36)\end{array}$ & $\begin{array}{l}-0.35^{* * *} \\
(-5.21)\end{array}$ & $\begin{array}{l}-0.25^{* * *} \\
(-3.70)\end{array}$ \\
\hline Size & & $\begin{array}{l}-0.24^{\text {*** }} \\
(-5.43)\end{array}$ & $\begin{array}{l}-0.20^{* * *} \\
(-4.71)\end{array}$ & & $\begin{array}{l}-0.24^{* * *} \\
(-5.66)\end{array}$ & $\begin{array}{l}-0.22^{* * *} \\
(-5.17)\end{array}$ & & $\begin{array}{l}-0.22^{* * *} \\
(-5.18)\end{array}$ & $\begin{array}{l}-0.20^{* * *} \\
(-4.71)\end{array}$ \\
\hline$B M$ & & $\begin{array}{l}0.39 * * * \\
(3.39)\end{array}$ & $\begin{array}{l}0.39 \text { *** } \\
(3.52)\end{array}$ & & $\begin{array}{l}0.40^{* * * *} \\
(3.49)\end{array}$ & $\begin{array}{l}0.42^{* * * *} \\
(3.69)\end{array}$ & & $\begin{array}{l}0.38^{* * * *} \\
(3.31)\end{array}$ & $\begin{array}{l}0.39 * * * \\
(3.51)\end{array}$ \\
\hline Past Month Returns & & $\begin{array}{l}-0.03^{* * *} \\
(-4.05)\end{array}$ & $\begin{array}{l}-0.05^{* * *} \\
(-6.14)\end{array}$ & & $\begin{array}{l}-0.03^{* * *} \\
(-4.00)\end{array}$ & $\begin{array}{l}-0.05^{* * *} \\
(-6.10)\end{array}$ & & $\begin{array}{l}-0.03^{* * *} \\
(-3.92)\end{array}$ & $\begin{array}{l}-0.05^{* * *} \\
(-6.04)\end{array}$ \\
\hline Fixed Effect & & & Month & & & Month & & & Month \\
\hline Number of observations & 52,444 & 48,460 & 48,460 & 52,444 & 48,460 & 48,460 & 52,444 & 48,460 & 48,460 \\
\hline
\end{tabular}




\section{Table A10: Performance of Routine and Opportunistic Trades across Exchanges}

This table reports pooled regressions of returns on indicators of routine and opportunistic trades in the prior month, across various exchanges. The sample period is 1989-2007. The dependent variable in each is future one-month returns (RET). Routine and opportunistic trades are defined as in Table I. Opportunistic Buy is a categorical variable equal to one if there were any opportunistic buys on a given firm in the prior month, and zero otherwise. Routine Buy is a categorical variable equal to one if there were any routine buys on a given firm in the prior month, and zero otherwise. Opportunistic Sell and Routine Sell are defined equivalently for insider sales. Columns 1 and 2 show regressions run on the full sample across all exchanges (these are identical to Columns 3 and 6 of Table II). Columns 2 and 3 show regression run only on the subsample of NYSE stocks, while Columns 5 and 6 show regressions run only the subsample of NASDAQ stocks. Size and BM are the natural logarithms of the firm characteristics of market equity and book-to-market of the given firm. Past Month (Year) Returns are the return of the given firm over the prior month (year, excluding the prior month $(t-2, t-12))$. Month fixed effects (Month) are included where indicated. Standard errors clustered at the firm level. $t$-statistics are shown below the estimates, and $1 \%, 5 \%$, and $10 \%$ statistical significance are indicated with $* * * * *$, and ${ }^{*}$, respectively.

\begin{tabular}{|c|c|c|c|c|c|c|}
\hline & $(1)$ & $(2)$ & $(3)$ & (4) & $(5)$ & $(6)$ \\
\hline & \multicolumn{2}{|c|}{$\begin{array}{c}\text { Baseline from paper } \\
\text { (Across all exchanges) }\end{array}$} & \multicolumn{2}{|c|}{ NYSE stocks only } & \multicolumn{2}{|c|}{ NASDAQ stocks only } \\
\hline Opportunistic Buy & $\begin{array}{l}0.90^{* * *} \\
(4.64)\end{array}$ & & $\begin{array}{l}1.21^{* * *} \\
(3.78)\end{array}$ & & $\begin{array}{l}0.75^{* *} \\
(2.25)\end{array}$ & \\
\hline Routine Buy & $\begin{array}{l}0.14 \\
(0.81)\end{array}$ & & $\begin{array}{l}0.62^{* *} \\
(2.42)\end{array}$ & & $\begin{array}{l}0.07 \\
(0.25)\end{array}$ & \\
\hline Opportunistic Sell & & $\begin{array}{l}-0.78^{* * *} \\
(-5.67)\end{array}$ & & $\begin{array}{l}-0.84^{* * *} \\
(-4.11)\end{array}$ & & $\begin{array}{l}-0.81^{* * *} \\
(-3.47)\end{array}$ \\
\hline Routine Sell & & $\begin{array}{l}0.04 \\
(0.24)\end{array}$ & & $\begin{array}{l}-0.33 \\
(-1.61)\end{array}$ & & $\begin{array}{l}0.23 \\
(0.91)\end{array}$ \\
\hline Size & $\begin{array}{l}-0.20 * * * \\
(-4.55)\end{array}$ & $\begin{array}{l}-0.20 * * * \\
(-4.70)\end{array}$ & $\begin{array}{l}-0.15^{* *} \\
(-2.53)\end{array}$ & $\begin{array}{l}-0.16^{* * *} \\
(-2.60)\end{array}$ & $\begin{array}{l}-0.32^{* * *} \\
(-3.42)\end{array}$ & $\begin{array}{l}-0.34^{* * *} \\
(-3.64)\end{array}$ \\
\hline$B M$ & $\begin{array}{l}0.37^{* * *} \\
(3.30)\end{array}$ & $\begin{array}{l}0.38^{* * *} \\
(3.42)\end{array}$ & $\begin{array}{l}0.21 \\
(1.45)\end{array}$ & $\begin{array}{l}0.26^{*} \\
(1.79)\end{array}$ & $\begin{array}{l}0.29 \\
(1.44)\end{array}$ & $\begin{array}{l}0.27 \\
(1.35)\end{array}$ \\
\hline Past Month Returns & $\begin{array}{l}-0.05^{* * *} \\
(-6.09)\end{array}$ & $\begin{array}{l}-0.05^{* * *} \\
(-6.03)\end{array}$ & $\begin{array}{l}-0.02^{*} \\
(-1.67)\end{array}$ & $\begin{array}{l}-0.02^{*} \\
(-1.66)\end{array}$ & $\begin{array}{l}-0.05^{* * *} \\
(-4.71)\end{array}$ & $\begin{array}{l}-0.05^{* * *} \\
(-4.66)\end{array}$ \\
\hline Past Year Returns & $\begin{array}{l}0.01^{* * *} \\
(4.71)\end{array}$ & $\begin{array}{l}0.01^{* * *} \\
(4.80)\end{array}$ & $\begin{array}{l}0.01^{*} \\
(1.90)\end{array}$ & $\begin{array}{l}0.01^{*} \\
(1.84)\end{array}$ & $\begin{array}{l}0.01 * * * \\
(3.06)\end{array}$ & $\begin{array}{l}0.01 * * * \\
(3.20)\end{array}$ \\
\hline Fixed Effect & Month & Month & Month & Month & Month & Month \\
\hline Number of observations & 48,460 & 48,460 & 14,021 & 14,021 & 21,558 & 21,558 \\
\hline
\end{tabular}




\section{Table A11: Robustness Checks}

This table reports pooled regressions of returns on indicators of routine and opportunistic trades in the prior month, from 1989-2007. The dependent variable in each is future one-month returns (RET). Routine and opportunistic trades are defined as in Table I. Opportunistic Buy is a categorical variable equal to one if there were any opportunistic buys on a given firm in the prior month, and zero otherwise. Routine Buy is a categorical variable equal to one if there were any routine buys on a given firm in the prior month, and zero otherwise. Opportunistic Sell and Routine Sell are defined equivalently for insider sales. Size and BM are the natural logarithms of market equity and book-to-market of the given firm. Columns 1 and 2 (3 and 4) include only stocks in the top (bottom) half of the market capitalization distribution, where market cap is measured in December of the prior year. Columns 5 and 6 ( 7 and 8) include only stocks in the top (bottom) half of the distribution of fraction of shares outstanding traded by insiders in the prior year. Columns 9 and 10 (11 and 12) include only those trades made within (outside) a 21-day trading window ( +3 to +24 days) after an earnings announcement, while also excluding (including) any trades that occur up to 30 days before an M\&A announcement. Month fixed effects (Month) are included where indicated. Standard errors clustered at the firm level. $t$-statistics are shown below the estimates, and $1 \%, 5 \%$, and $10 \%$ statistical significance are indicated with $* * *, * *$, and $*$, respectively.

\begin{tabular}{|c|c|c|c|c|c|c|c|c|c|c|c|c|}
\hline & (1) & $(2)$ & (3) & (4) & $(5)$ & (6) & $(7)$ & (8) & (9) & $(10)$ & (11) & $(12)$ \\
\hline & \multicolumn{2}{|c|}{ Large Stocks } & \multicolumn{2}{|c|}{ Small Stocks } & \multicolumn{2}{|c|}{$\begin{array}{c}\text { High Intensity } \\
\text { Stocks }\end{array}$} & \multicolumn{2}{|c|}{$\begin{array}{c}\text { Low Intensity } \\
\text { Stocks }\end{array}$} & \multicolumn{2}{|c|}{ Non-Blackout Only } & \multicolumn{2}{|c|}{ Blackout Only } \\
\hline Opportunistic Buy & $\begin{array}{l}0.55^{* *} \\
(2.31)\end{array}$ & & $\begin{array}{l}0.80^{* * *} \\
(2.78)\end{array}$ & & $\begin{array}{l}1.27^{* * *} \\
(4.14)\end{array}$ & & $\begin{array}{l}0.56^{* *} \\
(2.36)\end{array}$ & & $\begin{array}{l}1.28^{* * *} \\
(3.81)\end{array}$ & & $\begin{array}{l}0.85^{* * *} \\
(3.69)\end{array}$ & \\
\hline Routine Buy & $\begin{array}{l}0.08 \\
(0.37)\end{array}$ & & $\begin{array}{l}-0.01 \\
(-0.05)\end{array}$ & & $\begin{array}{l}0.46^{*} \\
(1.69)\end{array}$ & & $\begin{array}{l}-0.17 \\
(-0.80)\end{array}$ & & $\begin{array}{l}0.34 \\
(1.25)\end{array}$ & & $\begin{array}{l}0.14 \\
(0.70)\end{array}$ & \\
\hline Opportunistic Sell & & $\begin{array}{l}-0.55^{* * *} \\
(-3.44)\end{array}$ & & $\begin{array}{l}-0.83 * * * \\
(-3.29)\end{array}$ & & $\begin{array}{l}-1.13^{* * *} \\
(-5.45)\end{array}$ & & $\begin{array}{l}-0.39 * * \\
(-2.13)\end{array}$ & & $\begin{array}{l}-0.99 * * * \\
(-4.43)\end{array}$ & & $\begin{array}{l}-0.78^{* * *} \\
(-4.65)\end{array}$ \\
\hline Routine Sell & & $\begin{array}{l}0.11 \\
(0.62)\end{array}$ & & $\begin{array}{l}0.11 \\
(0.37)\end{array}$ & & $\begin{array}{l}-0.03 \\
(-0.14)\end{array}$ & & $\begin{array}{l}0.07 \\
(0.36)\end{array}$ & & $\begin{array}{l}-0.21 \\
(-0.90)\end{array}$ & & $\begin{array}{l}0.08 \\
(0.45)\end{array}$ \\
\hline Size & $\begin{array}{l}-0.08 \\
(-1.34)\end{array}$ & $\begin{array}{l}-0.08 \\
(-1.43)\end{array}$ & $\begin{array}{l}-0.50 \text { *** } \\
(-3.54)\end{array}$ & $\begin{array}{l}-0.50^{* * *} \\
(-3.50)\end{array}$ & $\begin{array}{l}-0.24^{* * *} \\
(-3.10)\end{array}$ & $\begin{array}{l}-0.25^{* * *} \\
(-3.28)\end{array}$ & $\begin{array}{l}-0.15^{* * *} \\
(-2.73)\end{array}$ & $\begin{array}{l}-0.15^{* * *} \\
(-2.78)\end{array}$ & $\begin{array}{l}-0.11 \\
(-1.57)\end{array}$ & $\begin{array}{l}-0.11^{*} \\
(-1.72)\end{array}$ & $\begin{array}{l}-0.22^{* * *} \\
(-4.27)\end{array}$ & $\begin{array}{l}-0.23^{* * *} \\
(-4.43)\end{array}$ \\
\hline$B M$ & $\begin{array}{l}0.40^{* * *} \\
(3.06)\end{array}$ & $\begin{array}{l}0.43^{* * *} \\
(3.27)\end{array}$ & $\begin{array}{l}0.23 \\
(1.26)\end{array}$ & $\begin{array}{l}0.22 \\
(1.18)\end{array}$ & $\begin{array}{l}0.34^{* *} \\
(2.14)\end{array}$ & $\begin{array}{l}0.37^{* *} \\
(2.33)\end{array}$ & $\begin{array}{l}0.39^{* *} \\
(2.44)\end{array}$ & $\begin{array}{l}0.39^{* *} \\
(2.41)\end{array}$ & $\begin{array}{l}0.37^{*} \\
(1.94)\end{array}$ & $\begin{array}{l}0.39^{* *} \\
(2.04)\end{array}$ & $\begin{array}{l}0.40^{* * *} \\
(3.10)\end{array}$ & $\begin{array}{l}0.42^{* * *} \\
(3.22)\end{array}$ \\
\hline Past Month Returns & $\begin{array}{l}-0.03 \text { *** } \\
(-2.87)\end{array}$ & $\begin{array}{l}-0.03^{* * *} \\
(-2.77)\end{array}$ & $\begin{array}{l}-0.06^{* * *} \\
(-5.62)\end{array}$ & $\begin{array}{l}-0.06^{* * *} \\
(-5.61)\end{array}$ & $\begin{array}{l}-0.05^{* * *} \\
(-4.45)\end{array}$ & $\begin{array}{l}-0.05^{* * *} \\
(-4.38)\end{array}$ & $\begin{array}{l}-0.06^{* * *} \\
(-4.46)\end{array}$ & $\begin{array}{l}-0.06^{* * *} \\
(-4.43)\end{array}$ & $\begin{array}{l}-0.03 * * * \\
(-2.84)\end{array}$ & $\begin{array}{l}-0.03^{* * *} \\
(-2.81)\end{array}$ & $\begin{array}{l}-0.06^{* * *} \\
(-6.60)\end{array}$ & $\begin{array}{l}-0.06^{* * *} \\
(-6.57)\end{array}$ \\
\hline Past Year Returns & $\begin{array}{l}0.01^{* * *} \\
(4.98)\end{array}$ & $\begin{array}{l}0.01 * * * \\
(5.06)\end{array}$ & $\begin{array}{l}0.00^{* *} \\
(2.21)\end{array}$ & $\begin{array}{l}0.00^{* *} \\
(2.30)\end{array}$ & $\begin{array}{l}0.01^{* * *} \\
(4.69)\end{array}$ & $\begin{array}{l}0.01^{* * *} \\
(4.81)\end{array}$ & $\begin{array}{l}0.01 \\
(1.39)\end{array}$ & $\begin{array}{l}0.01 \\
(1.41)\end{array}$ & $\begin{array}{l}0.01 \text { *** } \\
(2.63)\end{array}$ & $\begin{array}{l}0.01^{* * *} \\
(2.65)\end{array}$ & $\begin{array}{l}0.01^{* * *} \\
(3.35)\end{array}$ & $\begin{array}{l}0.01^{* * *} \\
(3.42)\end{array}$ \\
\hline Fixed Effect & Month & Month & Month & Month & Month & Month & Month & Month & Month & Month & Month & Month \\
\hline Number of observations & 26,543 & 26,543 & 21,927 & 21,927 & 26,345 & 26,345 & 22,115 & 22,115 & 17,594 & 17,594 & 36,605 & 36,605 \\
\hline
\end{tabular}




\section{Table A12: Predicting News Events with Opportunistic Buys and Sells Separately}

This table reports panel regressions of information events on the number of routine and opportunistic buys and sells in a company in the prior month, from 1989-2007. The dependent variables in the regressions are: in Columns 1-3, a proxy for firm information environment in month $t+1$ using the number of news, annual and quarterly earnings forecast revisions, recommendation changes, SEO and M\&A activities (All Firm Info), in Columns 4-6, solely the number of news in month $t+1$ (News). The main independent variables of interest are the Number of Opportunistic Buys, the Number of Opportunistic Sells, the Number of Routine Buys, and the Number of Routine Sells, each defined as the logarithm of one plus the number of trades of a given type, made in the prior month (month $t$ ). Past Month News is equal to the number of information events (for each respective specification of information events) observed for the given firm in the prior month (month $t$ ), while Past 6 Month News is defined equivalently for information events of the firm in the 6 months prior to last month. The other independent variables are defined in Table II. Month fixed effects (Month) are included where indicated. All standard errors are adjusted for clustering at the firm level, and t-stats using these clustered standard errors are included in parentheses below the coefficient estimates; $1 \%, 5 \%$, and $10 \%$ statistical significance are indicated with $* * *, * *$, and $*$, respectively.

\begin{tabular}{lllllll}
\hline & $(1)$ & $(2)$ & $(3)$ & $(4)$ & $(5)$ & $(6)$ \\
Type of Information: & All Firm Info & All Firm Info & All Firm Info & News & News & News \\
\hline Number of Opportunistic Sells & $0.26^{* * *}$ & $0.03^{* *}$ & $0.03^{* *}$ & $0.26^{* * *}$ & $0.03^{* * *}$ & $0.04^{* * *}$ \\
& $(8.18)$ & $(2.54)$ & $(2.37)$ & $(7.09)$ & $(2.85)$ & $(3.31)$ \\
Number of Opportunistic Buys & $-0.08^{* *}$ & 0.02 & $0.03^{* *}$ & 0.00 & $0.02^{*}$ & $0.02^{* *}$ \\
& $(-2.49)$ & $(1.58)$ & $(2.40)$ & $(0.13)$ & $(1.69)$ & $(2.01)$ \\
Number of Routine Sells & $0.31^{* * *}$ & $0.03^{*}$ & 0.02 & $0.26^{* * *}$ & 0.02 & 0.02 \\
& $(6.63)$ & $(1.72)$ & $(1.58)$ & $(4.49)$ & $(1.41)$ & $(1.33)$ \\
Number of Routine Buys & $-0.11^{* * *}$ & $-0.04^{* *}$ & 0.00 & -0.05 & -0.01 & 0.00 \\
& $(-3.17)$ & $(-2.29)$ & $(0.35)$ & $(-1.50)$ & $(-1.10)$ & $(0.05)$ \\
Size & & $0.09^{* * *}$ & $0.03^{* * *}$ & & $0.02^{* * *}$ & $0.02^{* * *}$ \\
& & $(15.87)$ & $(7.86)$ & & $(4.87)$ & $(4.66)$ \\
BM & & $-0.03^{* *}$ & -0.01 & & $-0.03^{* * *}$ & -0.01 \\
& & $(-2.42)$ & $(-1.37)$ & & $(-2.93)$ & $(-1.01)$ \\
Past Month Returns & $-0.00^{* *}$ & $0.00^{* * *}$ & & -0.00 & $0.00^{* * *}$ \\
Past Year Returns & & $(-2.02)$ & $(2.77)$ & & $(-0.97)$ & $(3.76)$ \\
Past Month News & & 0.00 & 0.00 & & 0.00 & 0.00 \\
Past 6 Month News & & $(0.44)$ & $(1.12)$ & & $(1.30)$ & $(1.09)$ \\
& & $0.58^{* * *}$ & $0.22^{* * *}$ & & $0.72^{* * *}$ & $0.28^{* * *}$ \\
Fixed Effect & & $(39.76)$ & $(19.36)$ & & $(54.63)$ & $(18.86)$ \\
Number of observations & & & $0.46^{* * *}$ & & & $0.39^{* * *}$ \\
\hline
\end{tabular}




\section{Exhibit A1: Hypothetical Example, and Notes on Opportunistic Insider Classification Scheme}

Assume you had insider Bob trade in March of 1987, 1988, and 1989 (and no other trades in those years). And here are his trades for 1990 and 1991:

1. January 1990

2. March 1990

3. Dec 1990

4. Jan 1991

In the main tables of our paper (i.e., everything except Table III), the "routine" trades are trades made by an insider who has had three consecutive calendar years with trades in the same month in the past. In the example above, insider Bob is routine. We would classify all his trades (1 through 4) as those made by a routine insider, and they would enter our tests as routine. In Table III, in our trade-level analysis, we took a slightly different approach. We wanted to differentiate trades that are made in the same month as the month that established an insider as routine from trades that the insider made in other (non-routine) months. In the example above, Bob is routine because he traded in March in three consecutive years. In Table III, all his subsequent March trades (i.e., trade 2) would be classified as routine. However, trades that Bob makes in months other than March (i.e., trades 1, 3, and 4) would be opportunistic in the context of Table III.

Some other notes about our classification scheme are as follows. In the results we report in the main tables (e.g., Table II), once a trader becomes routine, he is classified as routine for all of his subsequent trades, regardless of what trading behavior (or lack of trading behavior) takes place after his initial three-year classification period. We have experimented with different permutations here, e.g., only using the most recent three-year lagged trading behavior to define routine traders each year, and the results are very similar to those reported here (see Appendix Table A1). Finally, in all of our main results we do check the past three-years of trading for all opportunistic traders each year, so they can "become" a routine trader at any point. In which case, the opportunistic trader would become a routine trader if he traded in the same calendar month in the past three years, and then stay as a routine trader from that point onward as mentioned above. 